\title{
Zgodność z Konstytucją przepisu nowelizacji ustawy o odnawialnych źródłach energii oraz niektórych innych ustaw w zakresie terminu wejścia w życie ${ }^{1}$
}

\author{
Conformity to the Constitution of a provision of the Bill to Amend to the \\ Act on Renewable Energy Sources and Certain other Acts in Respect of the \\ Date of Entry into Force
}

\begin{abstract}
The Sejm's position is that the examined provision of the Act, which is being challenged by over a dozen communal and city councils, is in compliance with the principles of: non-retroactivity of the law, protection of trust towards the state and statutory law and constancy of tax law during a tax year, which are derived from the Constitution. The applicants demanded an examination of the constitutionality of the provision providing for a retroactive entry into force of the provisions giving new wording to the articles and the appendix to the Construction Law Act and the Act on Investments in Wind Farms. These provisions concern changes in the scope of the real estate tax on wind farms, which is the source of income for local self-government units. In the justification of the position, it was stated that the withdrawal from the cited constitutional principles is motivated by values approved in the Constitution.
\end{abstract}

Keywords: Constitutional Tribunal, taxes, local self-government

\footnotetext{
W stanowisku Sejmu stwierdzono, że zakwestionowany przez kilkanaście rad gmin i rad miejskich badany przepis ustawy jest zgodny z zasadami: nieretroakcji prawa, ochrony zaufania do państwa i stanowionego przez nie prawa oraz niezmienności prawa podatkowego w trakcie roku podatkowego, wywiedzionymi z Konstytucji RP. Wnioskodawcy domagali się zbadania konstytucyjności przepisu zakładającego wejście w życie z mocą wsteczną przepisów nadających nowe brzmienie artykułom i załącznikowi do ustawy - Prawo budowlane oraz ustawy o inwestycjach w zakresie elektrowni wiatrowych. Przepisy te dotyczą zmiany przedmiotowego zakresu podatku od nieruchomości od elektrowni wiatrowych, który stanowi źródło dochodów jednostek samorządu terytorialnego. W uzasadnieniu stanowiska stwierdzono, że odstąpienie od przywołanych wzorców konstytucyjnych motywowane jest wartościami aprobowanymi w ustawie zasadniczej. Słowa kluczowe: Trybunał Konstytucyjny, podatki, samorząd terytorialny

Doktor nauk prawnych, asystent -

Katolicki Uniwersytet Lubelski Jana Pawła II w Lublinie, Wydział Prawa, Prawa Kanonicznego i Administracji, Katedra Prawa Administracyjnego, LUBLIN, POLSKA • katarzyna.miaskowska-daszkiewicz@kul.lublin.pl • https://orcid.org/0000-0002-1898-8980
}

1 Sprawa zainicjowana wnioskiem Rady Gminy Świecie nad Osą z 20 sierpnia 2018 r. (sygn. akt K 4/19), połączonej ze sprawami o sygn. akt: K 5/19, K 6/19, K 7/19, K 8/19, K 9/19, K 10/19, K 11/19, K 12/19 i rozpoznawanej pod wspólną sygn. akt K 4/19, dotycząca ustawy z dnia 7 czerwca 2018 r. o zmianie ustawy o odnawialnych źródłach energii oraz niektórych innych ustaw, projekt stanowiska sporządzony 10 czerwca 2020 r.; BAS-WAK-831/19. 
Na podstawie art. 69 ust. 2 w związku z art. 42 pkt 3 ustawy z 30 listopada 2016 r. o organizacji i trybie postępowania przed Trybunałem Konstytucyjnym (t.j. Dz. U. 2019, poz. 2393), w imieniu Sejmu Rzeczypospolitej Polskiej przedkładam wyjaśnienia w sprawie zainicjowanej wnioskami Rady Gminy Świecie nad Osą z 20 sierpnia 2018 r. (sygn. akt K 4/19) oraz Rady Gminy Kobylnica z 31 maja 2019 r. (sygn. akt K 14/19), rozpoznawanych pod wspólną sygn. akt K 4/19, jednocześnie wnosząc o stwierdzenie, że art. 17 pkt 2 ustawy z 7 czerwca 2018 r. o zmianie ustawy o odnawialnych źródłach energii oraz niektórych innych ustaw (Dz. U. poz. 1276) jest zgodny z zasadami: nieretroakcji prawa, ochrony zaufania do państwa i stanowionego przez nie prawa oraz niezmienności prawa podatkowego w trakcie roku podatkowego, wywodzonymi z art. 2 Konstytucji, w związku $\mathrm{z}$ art. 167 ust. 3 Konstytucji.

Ponadto Sejm wnosi o umorzenie postępowania w pozostałym zakresie, na podstawie art. 59 ust. 1 pkt 2 ustawy o organizacji i trybie postępowania przed Trybunałem Konstytucyjnym, ze względu na niedopuszczalność wydania wyroku.

\section{Uzasadnienie}

\section{Uwagi wstępne}

W dniu 17 kwietnia 2019 r. do Kancelarii Sejmu wpłynęło zawiadomienie Prezes Trybunału Konstytucyjnego o wszczęciu postępowania przed Trybunałem Konstytucyjnym w sprawie wniosków: Rady Gminy Świecie nad Osą z 20 sierpnia 2018 r. (wpływ do TK - 21 sierpnia 2018 r.), sygn. akt K 4/19; Rady Gminy Lubowidz z 3 września 2018 r. (wpływ do TK - 6 września 2018 r.), sygn. akt K 5/19; Rady Gminy Dąbrowice z 3 września 2018 r. (wpływ do TK - 6 września 2018 r.), sygn. akt K 6/19; Rady Gminy Kamiennik z 3 września 2018 r. (wpływ do TK 6 września 2018 r.), sygn. akt K 7/19; Rady Gminy Rusiec z 4 września 2018 r. (wpływ do TK - 7 września 2018 r.), sygn. akt K 8/19; Rady Gminy Dygowo z 4 września 2018 r. (wpływ do TK - 7 września 2018 r.), sygn. akt K 9/19; Rady Miejskiej w Pelplinie z 6 września 2018 r. (wpływ do TK - 11 września 2018 r.), sygn. akt K 10/19; Rady Gminy Michów z 19 września 2018 r. (wpływ do TK 24 września 2018 r.), sygn. akt K 11/19 oraz Rady Gminy Stupsk z 26 września 2018 r. (wpływ do TK - 1 października 2018 r.), sygn. akt K 12/19.

Zarządzeniem Prezes TK wymienione wnioski zostały połączone w celu łącznego ich rozpoznania pod wspólną sygn. akt K 4/19, z uwagi na tożsamość przedmiotu spraw. Z tego samego względu do przywołanego postępowania dołączono wniosek Rady Gminy Kobylnica z 31 maja 2019 r. (wpływ do TK 5 czerwca 2019 r.), sygn. akt K 14/19, oraz wniosek Rady Miejskiej w Nowym Stawie z 18 czerwca 2019 r. (wpływ do TK - 25 sierpnia 2019 r.), sygn. akt K 19/19. 
Zarządzeniem Prezes Trybunału Konstytucyjnego z 21 kwietnia 2020 r. wnioski: Rady Gminy Lubowidz (sygn. akt K 5/19), Rady Gminy Dąbrowice (sygn. akt K 6/19), Rady Gminy Kamiennik (sygn. akt K 7/19), Rady Gminy Rusiec (sygn. akt K 8/19), Rady Gminy Dygowo (sygn. akt K 9/19), Rady Miejskiej w Pelplinie (sygn. akt K 10/19), Rady Gminy Michów (sygn. akt K 11/19), Rady Gminy Stupsk (sygn. akt K 12/19) i Rady Miejskiej w Nowym Stawie (sygn. akt K 19/19) zostały wyłączone do odrębnego rozpoznania.

Pod wspólną sygnaturą akt K 4/19 rozpoznawane są: wniosek Rady Gminy Świecie nad Osą (dalej: wniosek nr 1, wnioskodawczyni nr 1) oraz wniosek Rady Gminy Kobylnica (dalej: wniosek nr 2, wnioskodawczyni nr 2).

\section{Przedmiot kontroli}

1. Przedmiotem kontroli obie wnioskodawczynie uczyniły art. 17 pkt 2 ustawy z 7 czerwca 2018 r. o zmianie ustawy o odnawialnych źródłach energii oraz niektórych innych ustaw (Dz. U. poz. 1276; dalej: ustawa zmieniająca).

Kwestionowany przepis ma następujące brzmienie: „Ustawa wchodzi w życie po upływie 14 dni od dnia ogłoszenia, z wyjątkiem: [...] 2) art. 2 pkt 1 i 6 oraz art. 3 pkt 1, które wchodzą w życie z dniem następującym po dniu ogłoszenia, z mocą od dnia 1 stycznia 2018 r.".

Dla klarowności dalszego wywodu należy przywołać wskazane w treści kwestionowanego przepisu unormowania, zgodnie z którymi:

a) „W ustawie z dnia 7 lipca 1994 r. - Prawo budowlane (Dz. U. z 2018 r. poz. 1202) wprowadza się następujące zmiany: 1) w art. 3 pkt 3 otrzymuje brzmienie: «3) budowli - należy przez to rozumieć każdy obiekt budowlany niebędący budynkiem lub obiektem małej architektury, jak: obiekty liniowe, lotniska, mosty, wiadukty, estakady, tunele, przepusty, sieci techniczne, wolno stojące maszty antenowe, wolno stojące trwale związane z gruntem tablice reklamowe i urządzenia reklamowe, budowle ziemne, obronne (fortyfikacje), ochronne, hydrotechniczne, zbiorniki, wolno stojące instalacje przemysłowe lub urządzenia techniczne, oczyszczalnie ścieków, składowiska odpadów, stacje uzdatniania wody, konstrukcje oporowe, nadziemne i podziemne przejścia dla pieszych, sieci uzbrojenia terenu, budowle sportowe, cmentarze, pomniki, a także części budowlane urządzeń technicznych (kotłów, pieców przemysłowych, elektrowni jądrowych, elektrowni wiatrowych i innych urządzeń) oraz fundamenty pod maszyny i urządzenia, jako odrębne pod względem technicznym części przedmiotów składających się na całość użytkową»" (art. 2 pkt 1 ustawy zmieniającej);

a) „W ustawie z dnia 7 lipca 1994 r. - Prawo budowlane (Dz. U. z 2018 r. poz. 1202) wprowadza się następujące zmiany: [...] 6) w załączniku do ustawy wiersz «Kategoria XXIX - wolno stojące kominy i maszty oraz elektrownie wiatrowe» otrzymuje brzmienie: 


\begin{tabular}{|l|c|c|c|c|c|}
\hline & & \multicolumn{4}{|c|}{ Współczynnik wielkości obiektu (w) (wysokość w m) } \\
\hline & $\leq 20$ & $>20-50$ & $>50-100$ & $>100$ \\
\hline $\begin{array}{l}\text { Kategoria XXIX - wolno } \\
\text { stojące kominy i maszty } \\
\text { oraz części budowlane } \\
\text { elektrowni wiatrowych }\end{array}$ & 10,0 & 1,0 & 1,5 & 2,0 & 2,5 \\
\hline
\end{tabular}

(2 pkt 6 ustawy zmieniającej);

b) „W ustawie z dnia 20 maja 2016 r. o inwestycjach w zakresie elektrowni wiatrowych (Dz. U. poz. 961) wprowadza się następujące zmiany: 1) w art. 2 pkt 1 otrzymuje brzmienie: «1) elektrownia wiatrowa - instalację odnawialnego źródła energii, składającą się z części budowlanej stanowiącej budowlę w rozumieniu prawa budowlanego oraz urządzeń technicznych, w tym elementów technicznych, w której energia elektryczna jest wytwarzana $z$ energii wiatru, o mocy większej niż moc mikroinstalacji w rozumieniu art. 2 pkt 19 ustawy z dnia 20 lutego 2015 r. o odnawialnych źródłach energii (Dz. U. z 2018 r. poz. 1269 i 1276) [aktualnie: t.j. Dz. U. 2020, poz. 261, ze zm. - uwaga K.M.-D.]»" (art. 3 pkt 1 ustawy zmieniającej).

2. W odniesieniu do przedmiotu kontroli należy dodać, że w obu wnioskach posłużono się zakresową formułą zaskarżenia, co sugerowałoby, że inicjatorki niniejszego postępowania kwestionują nie brzmienie przepisu in extenso, ale jego treść w ograniczonym wymiarze.

Rada Gminy Świecie nad Osą domaga się zbadania konstytucyjności art. 17 pkt 2 ustawy zmieniającej „w zakresie, w jakim przewiduje wejście w życie z mocą wsteczną od dnia 1.01.2018 r. art. 2 pkt 1 i 6 oraz art. 3 pkt 1 tej Ustawy, nadających nowe brzmienie art. 3 pkt 3 i załącznikowi do Ustawy z dnia 7 lipca 1994 r. - Prawo budowlane (Dz. U. z 2018 r. poz. 1202 ze zm.) oraz art. 2 pkt 1 Ustawy z dnia 20 maja 2016 r. o inwestycjach w zakresie elektrowni wiatrowych (Dz. U. poz. 961)”.

Natomiast precyzując przedmiot zaskarżenia w swoim wniosku, Rada Gminy Kobylnica wskazała, iż wnosi o zbadanie art. 17 pkt 2 ustawy zmieniającej „w zakresie $\mathrm{w}$ jakim przewiduje on wejście $\mathrm{w}$ życie przepisu art. 2 pkt 1 i 6 oraz art. 3 pkt 1 tejże ustawy z mocą wsteczną, tj. od dnia 1 stycznia 2018 r.”.

W związku z powyższym należy odnotować, że analiza treści normatywnej zakwestionowanego przepisu i konfrontacja jej z przywołanymi zakresami zaskarżenia sformułowanymi we wnioskach prowadzi do konkluzji, że w istocie zawartość zaskarżonego art. 17 ust. 2 ustawy zmieniającej wyczerpuje przywołane przez wnioskodawczynie zakresy zaskarżenia. Przepis ten bowiem nie zawiera żadnej innej dodatkowej treści, która nie podlegałaby zaskarżeniu.

$\mathrm{Z}$ tego względu Sejm, odwołując się do zasady falsa demonstratio non nocet, która nakazuje odczytywać zakres zaskarżenia zgodnie $\mathrm{z}$ intencjami podmiotu uruchamiającego postępowanie przed sądem konstytucyjnym, skłania się ku zmianie sposobu oznaczenia przedmiotu kontroli i wskazania jako taki art. 17 pkt 2 ustawy zmieniającej, bez doprecyzowania jego zakresu. 
3. Szczegółowa analiza przedmiotu kontroli zostanie dokonana w części niniejszego stanowiska poświęconej analizie zgodności.

\section{Zarzuty wnioskodawczyń}

1. Wnioskodawczyni nr 1 zakwestionowała zgodność art. 17 pkt 2 ustawy zmieniającej z zasadami wywodzonymi z zasady demokratycznego państwa prawnego (art. 2 Konstytucji): zasadą lex retro non agit, zasadą zaufania obywatela do państwa i stanowionego przez nie prawa (pewności prawa), zasadą ochrony praw nabytych, zasadą przyzwoitej legislacji i zakazem zmiany przepisów podatkowych w trakcie trwania roku podatkowego. Jako przepis związkowy wskazano przy tym art. 167 Konstytucji, wyrażający zasadę samodzielności finansowej jednostek samorządu terytorialnego.

W uzasadnieniu zarzutów wnioskodawczyni nr 1 podkreśliła, że zmiany wprowadzone na mocy art. 17 pkt 2 ustawy zmieniającej mają istotne znaczenie dla gmin jako jednostek samorządu terytorialnego, ponieważ bezpośrednio determinują one wysokość ich dochodów. Wpływy z podatku od nieruchomości, in casu od elektrowni wiatrowych, stanowią bowiem źródło dochodów jednostek samorządu terytorialnego

Zgodnie $\mathrm{z}$ art. 2 ust. 1 pkt 3 ustawy z 12 stycznia 1991 r. o podatkach i opłatach lokalnych (t.j. Dz. U. 2019, poz. 1170, ze zm., dalej: u.p.o.l.), opodatkowaniu podatkiem od nieruchomości podlegają budowle lub ich części związane z prowadzeniem działalności gospodarczej. Dla potrzeb podatku od nieruchomości za budowlę uznaje się obiekt budowlany w rozumieniu przepisów prawa budowlanego niebędący budynkiem lub obiektem małej architektury, a także urządzenia budowlane $\mathrm{w}$ rozumieniu przepisów prawa budowlanego związane $\mathrm{z}$ obiektem budowlanym, które zapewniają możliwość użytkowania obiektu zgodnie z jego przeznaczeniem (art. 1a ust. 1 pkt 2 u.p.o.l.).

Wnioskodawczyni nr 1 wskazuje, iż: „, $[\mathrm{k}]$ ażda zatem zmiana definicji budowli w Prawie budowlanym (czy też prawie budowlanym rozumianym szeroko jako zbiór ustaw normujących kwestie związane $\mathrm{z}$ budownictwem) powoduje zmianę w zakresie opodatkowania budowli podatkiem od nieruchomości, który stanowi wyłączny dochód gmin" (wniosek nr 1, s. 4).

W wyniku konstrukcji zaskarżonej regulacji przyjętej 7 czerwca 2018 r. od 1 stycznia 2018 r. opodatkowaniu podlega część budowlana elektrowni wiatrowej bez urządzeń technicznych, podczas gdy w poprzednio obowiązującym stanie prawnym opodatkowaniu podlegała cała elektrownia wiatrowa (część budowlana wraz z częścią techniczną).

Wnioskodawczyni nr 1 argumentuje, że tym samym, ze względu na zmianę definicji budowli i definicji elektrowni wiatrowej oraz datę wejścia w życie tych zmian, jednostka samorządu terytorialnego przez nią reprezentowana została pozbawiona części swoich dochodów (swojej samodzielności finansowej). Ponadto na mocy wstecznego obowiązywania przepisów wskazanych w art. 17 pkt 2 
ustawy zmieniającej, zobowiązana została do zwrotu uiszczonego już podatku od nieruchomości od elektrowni wiatrowych posadowionych na jej terenie.

$\mathrm{Z}$ analizy wniosku nr 1 wynika, że wnioskodawczyni nr 1, dostrzegając pojemność normatywną art. 2 Konstytucji, diagnozuje naruszenie kilku zasad szczegółowych wywodzonych z tego wzorca kontroli.

Po pierwsze, argumentuje, że art. 17 pkt 2 ustawy zmieniającej narusza zasadę ochrony zaufania do państwa i stanowionego przez nie prawa, którą należy odnosić również do jednostek samorządu terytorialnego.

Po drugie, wywodzi złamanie zasady ochrony praw nabytych oraz interesów w toku.

Po trzecie, stwierdza naruszenie zasady lex retro non agit, przy jednoczesnym braku wskazania w uzasadnieniu ustawy zmieniającej wartości konstytucyjnej, która usprawiedliwiałaby zdiagnozowaną retroakcję. Wnioskodawczyni nr 1 powołując się na wyrok TK z 20 stycznia 2010 r., sygn. akt Kp 6/09 - wskazuje, że adresatem zasady lex retro non agit są także jednostki samorządu terytorialnego, ponieważ art. 2 Konstytucji wyznacza konstytucyjną sytuację prawną nie tylko jednostki, a więc obywateli i osób, ale również jednostek samorządu terytorialnego (wniosek nr 1, s. 5).

Po czwarte, wskazuje na przekroczenie wynikającego bezwzględnie z art. 2 Konstytucji zakazu zmiany prawa podatkowego w trakcie trwania roku podatkowego.

Po piąte wreszcie, wywodzi naruszenie przez kwestionowany przepis art. 167 Konstytucji, statuujący zasadę samodzielności samorządu terytorialnego, której jednym z elementów składowych jest zasada samodzielności finansowej.

We wniosku nr 1 argumentuje się, że Rada Gminy Świecie nad Osą działała $\mathrm{w}$ pełni racjonalnie, uchwalając budżet gminy w terminie ustawowym i w zgodzie z obowiązującym wówczas prawem, uwzględniając dochody z tytułu podatku od nieruchomości, których wysokość decydowała o skali planowanych przedsięwzięć. Dochody z tytułu podatku od nieruchomości za rok 2018 nie zostały określone w budżecie tej jednostki samorządu terytorialnego jako rezerwa lub lokata i na ich podstawie zostały zaplanowane konkretne wydatki. Podniesiono, że skoro zasadą jest, iż budżet jednostki samorządu terytorialnego nie przewiduje nadwyżki budżetowej, a gromadzone dochody nie stanowią rezerwy ani lokaty, to braki w zakresie dochodów skutkują niemożliwością pokrycia przewidywanych wydatków przede wszystkim związanych z realizacją zadań własnych. W konsekwencji, zwłaszcza w przypadku małych gmin, na terenie których zlokalizowane są elektrownie wiatrowe, prowadzi to do pogorszenia jakości życia ich mieszkańców (wniosek nr 1, s. 7).

W opinii wnioskodawczyni nr 1 powołane powyżej zasady konstytucyjne wynikające $\mathrm{z}$ art. 2 Konstytucji, w tym w szczególności zakaz zmiany przepisów prawa podatkowego $\mathrm{w}$ trakcie trwania roku podatkowego, jak i zasada samodzielności finansowej jednostek samorządu terytorialnego, nakazywały jej po- 
dejmowanie działań w zaufaniu do obowiązującego stanu prawnego i w żaden sposób nie pozwalały na przewidzenie, że władza ustawodawcza w trakcie roku budżetowego pozbawi ją znacznej części dochodów. „O ile więc w granicach określonych ustawą, zgodnie $\mathrm{z}$ art. 167 ust. 3 Konstytucji, ustawodawca może kształtować wysokość dochodów własnych gmin, w tym z tytułu podatku od nieruchomości, o tyle powinien w tym względzie mieć na uwadze również zasadę adekwatności wyrażoną w ust. 1 tego przepisu. Udział w dochodach publicznych powinien być odpowiedni do przypadających jednostkom samorządu terytorialnego zadań. Skoro więc następuje obniżenie tych dochodów bez zmniejszenia zadań oraz bez właściwej rekompensaty utraconych dochodów, to zasada ta jest zachwiana ze szkodą dla społeczności lokalnej, wobec której samorząd pełni funkcję służebną" (ibidem).

Ponadto wnioskodawczyni nr 1 zadeklarowała, że w pełni popiera i przyjmuje jako własne stanowisko wyrażone w ekspertyzie prawnej, załączonej do uchwały Rady Gminy Świecie nad Osą, a sporządzonej przez dr. hab. Rafała Dowgiera i dr. Artura Olechno z Uniwersytetu w Białymstoku, w związku z czym nie będzie powielała argumentów tam zawartych, wnosząc o uwzględnienie tych argumentów. W tym miejscu Sejm uznaje za stosowne podnieść, że jego wątpliwości budzi przywołana konstrukcja uzasadnienia wniosku, nakazująca poszukiwanie argumentacji na rzecz niezgodności z Konstytucją w ekspertyzie dołączonej do niego.

2. Z kolei we wniosku nr 2 zdiagnozowano problem konstytucyjny wyłącznie w perspektywie art. 2 Konstytucji RP, wskazując, że kwestionowana regulacja narusza zasadę zaufania do państwa i stanowionego przez nie prawa oraz zasadę nieretroakcji.

W uzasadnieniu zarzutów wnioskodawczyni nr 2 stwierdziła, że „w przedmiotowej sprawie Ustawa Nowelizująca bez wątpienia wprowadziła przepisami art. 17 pkt 2 niedozwoloną regulację retroaktywną, gdyż przepis ten przewiduje, że art. 2 pkt 1 i 6 oraz art. 3 pkt 1 Ustawy Nowelizującej (a zatem przepisy wpływające bezpośrednio na wymiar daniny) wchodzą w życie z dniem 30 czerwca 2018 r., z mocą od dnia 1 stycznia 2018 r. Wskazana regulacja godzi w zasadę lex retro non agit, stanowiącą istotny składnik zasady zaufania obywateli do państwa oraz zasady pewności prawa, wywodzących się z zasady demokratycznego państwa prawnego proklamowanej przez art. 2 Konstytucji RP" (wniosek nr 2, s. 14).

Jednocześnie, po dokonaniu analizy orzecznictwa Trybunału Konstytucyjnego, wnioskodawczyni nr 2 stwierdziła, że w świetle poglądów TK, w odniesieniu do przedmiotowej sprawy nie sposób wskazać okoliczności, które usprawiedliwiałyby odstępstwo od zasady lex retro non agit, bowiem w uzasadnieniu projektu ustawy zmieniającej „w zasadzie brak jest wytłumaczenia wprowadzenia zaskarżonego przepisu z mocą wsteczną [...] trudno byłoby racjonalnie twierdzić, iż retroaktywność wiązała się z potrzebą realizacji czy ochroną pewnej (bliżej nieokreślonej) zasady prawno-konstytucyjnej. Nie wskazują na to także zawarte 
w uzasadnieniu przewidywane skutki wprowadzenia zaskarżonej regulacji (społeczne, gospodarcze i finansowe)" (wniosek nr 2, s. 16).

We wniosku nr 2 wywiedziono ponadto, że nie można uznać za adekwatne usprawiedliwienie powołanie się projektodawcy na treść decyzji Komisji Europejskiej z 13 grudnia 2017 r., o sygn. SG-Grcffe(2017)D/19933, ponieważ decyzja ta „przewiduje zobowiązanie władz polskich (podjęte jeszcze w 2017 r.), aby zapewnić wejście w życie Ustawy Nowelizującej [ustawy zmieniającej - uwaga K.M.-D.] - w tym zmiany podatku od nieruchomości - nie później niż 1 stycznia 2018 r. Niewprowadzenie zmian w zakreślonym terminie nie tłumaczy więc wprowadzania przez ustawodawcę przepisów ze skutkiem retroaktywnym. [...] Stan, w którym to na gminy przerzucony został ciężar finansowy związany z brakiem odpowiednio szybkiego działania ustawodawcy (a więc do dnia 1 stycznia 2018 r.) nie jest z pewnością realizacją "przyjętego zobowiązania międzynarodowego». Deklaracja Rządu wprost odnosiła się do zmiany cen referencyjnych, a nie do wprowadzania zmian w prawie z mocą wsteczną. Tym samym deklaracja ta nie może stanowić uzasadnionej podstawy do dokonania odstępstwa od zasady lex retro non agit, wyrażonej pośrednio w art. 2 Konstytucji RP” (wniosek nr 2, s. 18).

\section{Analiza formalnoprawna}

1. W pierwszej kolejności rozważenia wymaga legitymacja wnioskodawczyń w niniejszej sprawie.

Postępowanie przed Trybunałem Konstytucyjnym zostało zainicjowane przez organy stanowiące jednostek samorządu terytorialnego. Zgodnie z art. 191 ust. 1 pkt 3 w związku $\mathrm{z}$ art. 188 Konstytucji, organy stanowiące jednostek samorządu terytorialnego mogą wystąpić do Trybunału z wnioskiem w sprawie zbadania zgodności ustaw z Konstytucją oraz z ratyfikowanymi umowami międzynarodowymi, których ratyfikacja wymagała uprzedniej zgody wyrażonej w ustawie. Ustanowiony w art. 191 ust. 2 Konstytucji warunek dopuszczalności złożenia wniosku do Trybunału Konstytucyjnego przez organ stanowiący jednostki samorządu terytorialnego polega na wymaganiu istnienia związku między zaskarżonym przepisem a sprawami objętymi zakresem działania tego rodzaju jednostek. Sposób rozumienia przesłanki „sprawy objęte zakresem działania” na gruncie art. 191 ust. 2 Konstytucji stanowi przedmiot utrwalonej linii orzeczniczej sądu konstytucyjnego, który uznaje ją za spełnioną wówczas, gdy kwestionowany przepis wyznacza kompetencje jednostki samorządu terytorialnego bądź dotyczy bezpośrednio spraw tej jednostki (zob. wyroki TK z: 9 czerwca 2010 r., sygn. akt K 29/07, i 13 lipca 2011 r., sygn. akt K 10/09).

2. Rozstrzygając kwestię legitymacji procesowej wnioskodawczyń w niniejszym postępowaniu, należy stwierdzić, że w świetle art. $15 \mathrm{w}$ związku z art. 11a ust. 1 pkt 1 ustawy z 8 marca 1990 r. o samorządzie gminnym (t.j Dz. U. 2020, poz. 713) są one organami stanowiącymi jednostek samorządu terytorialnego i wystąpiły z wnioskami do Trybunału na podstawie podjętych uchwał dołączo- 
nych do wniosków, czym zadośćuczyniono wymogowi płynącemu z art. 48 ust. 2 pkt 1 ustawy 30 listopada 2016 r. o organizacji i trybie postępowania przed Trybunałem Konstytucyjnym (t.j. Dz. U. 2019, poz. 2393; dalej: ustawa o TK).

Zgodnie z art. 4 ust. 1 pkt 1 lit. a ustawy z 13 listopada 2003 r. o dochodach jednostek samorządu terytorialnego (t.j. Dz. U. 2020, poz. 23, ze zm.) źródłami dochodów własnych gminy są wpływy z podatku od nieruchomości.

Zaskarżonym przepisem zastosowano mechanizm retroakcji w odniesieniu do art. 2 pkt 1 i 6 oraz art. 3 pkt 1 ustawy zmieniającej. Przepisy te zmodyfikowały zakres przedmiotowy opodatkowania podatkiem od nieruchomości elektrowni wiatrowych, obejmując nim wyłącznie ich części budowlane. Tym samym, zważywszy, że podstawą wymiaru podatku od nieruchomości w odniesieniu do budowli jest ich wartość (art. 4 ust. 1 pkt 3 u.p.o.l.), obniżeniu uległy wpływy podatkowe $\mathrm{w}$ gminach, na terenie których ulokowano tzw. farmy wiatrowe. Nie ulega więc wątpliwości, że kwestionowana regulacja ma wpływ na dochody jednostek samorządu terytorialnego, których organami są wnioskodawczynie, a tym samym dotyczy bezpośrednio ich spraw.

Warto odnotować, że w wyroku z 13 lipca 2011 r. (sygn. akt K 10/09) Trybunał, orzekając w pełnym składzie, wyraził pogląd, że „interes ekonomiczny (faktyczny) gminy [...] stanowi adekwatną przesłankę wystąpienia z wnioskiem do Trybunału Konstytucyjnego". Zdaniem Trybunału, ze względu na wyrażone w Konstytucji zasady dotyczące samodzielności jednostek samorządu terytorialnego, „trudno jest zaaprobować stanowisko, że przepisy oddziałujące w sposób bezpośredni na wysokość dochodów warunkujących sposób wykonywania przez gminę jej zadań nie dotyczą spraw objętych zakresem działania gminy”.

3. Ustalenie legitymacji procesowej wnioskodawczyń nie wyczerpuje zagadnień formalnoprawnych $w$ niniejszej sprawie, bowiem analiza treści uzasadnienia wniosku nr 1 ujawnia deficyty w jego warstwie argumentacyjnej, co wywołuje wątpliwości Sejmu co do dopuszczalności merytorycznego orzekania względem niektórych wzorców kontroli.

Sejm pragnie przypomnieć, że w art. 47 ust. 1 ustawy o TK sprecyzowane zostały wymogi, jakim powinny odpowiadać wnioski składane do Trybunału Konstytucyjnego, aby skutecznie zainicjować hierarchiczną kontrolę norm. Elementami niezbędnymi uzasadnienia wniosku, w świetle art. 47 ust. 2 ustawy o TK, są m.in.: „przywołanie treści kwestionowanego wnioskiem przepisu wraz z jego wykładnią” (pkt 1), „przywołanie wzorców kontroli wraz z ich wykładnią” (pkt 2), „określenie problemu konstytucyjnego i zarzutu niekonstytucyjności” (pkt 3) oraz „wskazanie argumentów lub dowodów na poparcie zarzutu niekonstytucyjności” (pkt 4).

Trybunał Konstytucyjny związany jest zarzutami określonymi w piśmie procesowym, pochodzącym od podmiotu uprawnionego do inicjowania postępowania. W tym zakresie zaś istotne znaczenie ma należyte uzasadnienie zarzutów. Wskazywane w piśmie procesowym argumenty „zawsze muszą być argumenta- 
mi „nadającymi się” do rozpoznania przez Trybunał Konstytucyjny” (wyrok TK z 19 października 2010 r., sygn. akt P 10/10).

Kontrola konstytucyjności ustaw przebiega na podstawie domniemania, że badane normy są zgodne z Konstytucją. Ciężar dowodu spoczywa na podmiocie kwestionującym zgodność ustawy z Konstytucją. Obowiązkiem wnioskodawcy jest więc przedstawienie argumentów, przemawiających za stwierdzeniem niezgodności zaskarżonych norm prawnych z normami powołanymi jako podstawa kontroli (zob. K. Wojtyczek, Ciężar dowodu i argumentacji w procedurze kontroli norm przez Trybunał Konstytucyjny, „Przegląd Sejmowy” 2004, nr 1, s. 17).

Nie jest więc wystarczające sformułowanie samej tezy o niekonstytucyjności zaskarżonego przepisu. Zdaniem Trybunału Konstytucyjnego: „Uzasadnienie musi spełniać określone wymagania, w tym przede wszystkim precyzyjnie wskazywać co najmniej jeden argument przemawiający za naruszeniem określonych wzorców kontroli. Nie realizują omawianych wymagań uwagi nazbyt ogólne, niejasne czy też czynione jedynie na marginesie innych rozważań. Należy przy tym odróżnić uzasadnienie pozorne i uzasadnienie błędne czy nietrafne. Postawienie bezzasadnego zarzutu prowadzi do uznania aktu normatywnego za zgodny z danym przepisem Konstytucji, ewentualnie do stwierdzenia nieadekwatności wzorca kontroli, natomiast błędne czy nietrafne uzasadnienie, o ile nie wpływa na rekonstrukcję nieprecyzyjnie sformułowanego zarzutu, nie ma znaczenia dla rozstrzygnięcia $\mathrm{w}$ przedmiocie zgodności aktu normatywnego z ustawą zasadniczą" (zob. np. wyrok TK z 5 czerwca 2014 r., sygn. akt K 35/11).

Zatem przepisy ustawy o TK nakładają na podmioty uprawnione do złożenia wniosku (pytania, skargi) do sądu konstytucyjnego pewne obowiązki, w tym wymóg uzasadnienia postawionego zarzutu, z powołaniem dowodów na jego poparcie. Trybunał Konstytucyjny, we wcześniejszym orzecznictwie, które zachowuje pełną aktualność na tle obowiązującego stanu prawnego, podkreślał, że „uzasadnienie zarzutów powinno opierać się na przedstawieniu we wniosku takiej argumentacji, która uprawdopodobni ewentualną niekonstytucyjność kwestionowanych przepisów. W szczególności argumentacja taka nie może opierać się jedynie na odczuciach czy wyobrażeniach wnioskodawcy, ale powinna być poparta merytorycznym uzasadnieniem, mogącym uwzględniać m.in. wcześniejsze orzecznictwo TK, praktykę stosowania prawa czy dorobek doktryny" (postanowienie TK z 6 listopada 2007 r., sygn. akt Tw 41/05; zob. także postanowienia TK z: 12 sierpnia 2005 r., sygn. akt Tw 23/05, i 29 sierpnia 2006 r., sygn. akt Tw 14/06). Samo werbalne sformułowanie zarzutu, czy też wskazanie, że kwestionowany przepis jest sprzeczny z innym przepisem aktu hierarchicznie wyższego nie może więc zostać uznane za uzasadnienie zarzutu w sensie procesowym. Zgodnie $\mathrm{z}$ art. 67 ustawy o TK Trybunał Konstytucyjny jest bowiem związany treścią oraz granicami rozpatrywanego wniosku, pytania prawnego lub skargi. Tym samym nie może on - wychodząc poza granice określone w piśmie inicjującym postępowanie - wyręczać inicjatora tego postępowania w doborze argumentacji 
adekwatnej do podnoszonych wątpliwości. Brak odpowiedniego uzasadnienia zarzutu niezgodności danego przepisu z przywołanymi wzorcami kontroli stanowi o uchybieniu przez wnioskodawcę ustawowej powinności określonej w art. 47 ust. 2 pkt 4 ustawy o TK i skutkuje brakiem możliwości jego rozpatrzenia przez sąd konstytucyjny oraz koniecznością umorzenia postępowania ze względu na niedopuszczalność wydania wyroku (art. 59 ust. 1 pkt 2 ustawy o TK).

4. Odnosząc poczynione ustalenia do pism procesowych inicjujących niniejsze postępowanie, należy odnotować, że we wniosku nr 1 sformułowano zarzut niezgodności art. 17 pkt 2 ustawy zmieniającej z art. 167 Konstytucji. Abstrahując od tego, że w petitum tego wniosku wzorzec ten jest wskazywany jako związkowy względem art. 2, natomiast $\mathrm{z}$ analizy jego uzasadnienia wynika, iż wnioskodawczyni nr 1 upatruje w przywołanym przepisie Konstytucji samodzielną podstawę kontroli, Sejm stwierdza, że w analizowanym wniosku nie dostrzega się złożonej treści art. 167 Konstytucji, który składa się z kilku jednostek redakcyjnych i pozwala na rekonstrukcję różnych norm konstytucyjnych. Zgodnie z brzmieniem tego przepisu: „Jednostkom samorządu terytorialnego zapewnia się udział w dochodach publicznych odpowiednio do przypadających im zadań” (ust. 1); „Dochodami jednostek samorządu terytorialnego są ich dochody własne oraz subwencje ogólne i dotacje celowe z budżetu państwa” (ust. 2); „Źródła dochodów jednostek samorządu terytorialnego są określone w ustawie” (ust. 3); „Zmiany w zakresie zadań i kompetencji jednostek samorządu terytorialnego następują wraz z odpowiednimi zmianami w podziale dochodów publicznych" (ust. 4).

Niewątpliwie zakresy normowania wymienionych ustępów są ze sobą funkcjonalnie powiązane i stanowią - w świetle ugruntowanego orzecznictwa konstytucyjnego - emanację zasady samodzielności jednostek samorządu terytorialnego w aspekcie finansowym, na którą powołuje się wnioskodawczyni nr 1 . Należy jednak podkreślić, że każdy z nich ma własną treść, a ocena, czy wyrażone w nich normy zostały zrealizowane albo przekroczone, powinna być przeprowadzona dla każdego ustępu osobno. Wnioskodawczyni nr 1, powołując art. 167 Konstytucji, wskazuje, iż „kwintesencją samodzielności finansowej jednostek samorządu terytorialnego jest art. 167 ust. 3 Konstytucji (...)" (wniosek nr 1, s. 6), dając tym samym wskazówkę, że w tym komponencie art. 167 Konstytucji upatruje wzorca kontroli. Ponadto we wniosku nr 1 podniesiono, że: „O ile więc w granicach określonych ustawą, zgodnie $\mathrm{z}$ art. 167 ust. 3 Konstytucji, ustawodawca może kształtować wysokość dochodów własnych gmin, w tym z tytułu podatku od nieruchomości, o tyle powinien w tym względzie mieć na uwadze również zasadę adekwatności wyrażoną w ust. 1 tego przepisu. Udział w dochodach publicznych powinien być odpowiedni do przypadających jednostkom samorządu terytorialnego zadań. Skoro więc następuje obniżenie tych dochodów bez zmniejszenia zadań oraz bez właściwej rekompensaty utraconych dochodów, to zasada ta jest zachwiana ze szkodą dla społeczności lokalnej, wobec której samorząd pełni funkcję służebną" (ibidem). 
Z perspektywy wymogów rządzących postępowaniem przed Trybunałem Konstytucyjnym, Sejm uznaje, że Rada Gminy Świecie nad Osą w żaden sposób nie uzasadniła, w jaki sposób zakwestionowany art. 17 pkt 2 ustawy zmieniającej koliduje z ust. 2 i ust. 4 art. 167 Konstytucji, co uzasadnia wniosek o umorzenie postępowania w zakresie badania zaskarżonej regulacji z tymi wzorcami kontroli, ze względu na niedopuszczalność wydania wyroku.

5. Przechodząc do wskazanego we wniosku $\mathrm{nr} 1$ wzorca wynikającego $\mathrm{z}$ art. 167 ust. 1 Konstytucji, trzeba podkreślić, że zgodnie ze stanowiskiem Trybunału Konstytucyjnego, z naruszeniem zasady adekwatności mamy do czynienia wówczas, gdy stosowanie zakwestionowanych przepisów prowadzi do sytuacji, w której „całokształt źródeł dochodów - przewidzianych przez prawo - dla jednostek samorządu terytorialnego danego szczebla nie zapewnia tym jednostkom udziału w dochodach publicznych «odpowiednio» do przypadających im zadań" (wyrok TK z 31 stycznia 2013 r., sygn. akt K 14/11, i cytowane tam orzecznictwo). Jak podkreślał Trybunał, zasada adekwatności ma przede wszystkim charakter dyrektywy programowej, adresowanej do ustawodawcy, „natomiast zasada adekwatności rozumiana jako wiążąca norma prawna ma dużo węższy zakres normowania sprowadzający się do zakazu przyznawania j.s.t. [jednostkom samorządu terytorialnego - dopisek K.M.-D.] środków finansowych na poziomie uniemożliwiającym wykonanie powierzonych im zadań”. Należy przy tym „uwzględnić szeroki margines oceny, jaki prawodawca konstytucyjny pozostawił legislatywie w związku z alokacją środków finansowych", a w kompetencji Trybunału Konstytucyjnego nie leży kontrola decyzji w tym zakresie z punktu widzenia ich trafności. Trybunał Konstytucyjny ingeruje w sferę swobody politycznej parlamentu jedynie w wypadku ewidentnie niewspółmiernego ukształtowania dochodów w relacji do kosztów ponoszonych w związku z realizacją przypadających samorządowi zadań, wówczas gdy dochodzi do „oczywistych dysproporcji” między zakresem zadań a środkami, w jakie wyposażone zostają jednostki samorządu terytorialnego. Podmiot, który kwestionuje zgodność aktu normatywnego z art. 167 ust. 1 Konstytucji, nie może ograniczyć się do wykazania, że dochody jednostek samorządu terytorialnego nie wystarczają na realizację zadań publicznych, ale musi przedstawić argumenty wskazujące na dysproporcję między zakresem zadań i dochodów administracji rządowej oraz poszczególnych szczebli samorządu terytorialnego (zob. wyrok TK z 7 czerwca 2001 r., sygn. akt K 20/00). „Chodzi o to, by wpływy z dochodów własnych, subwencji i dotacji zapewniały wszystkim samorządom możność wypełniania - przynajmniej na poziomie minimalnym - zadań, które ustawowo i obligatoryjnie są na samorząd nałożone. Tak należy rozumieć zasadę adekwatności” (wyrok z 25 lipca 2006 r., sygn. akt K 30/04).

W ocenie Sejmu we wniosku nr 1 nie wykazano w żaden sposób, że zaskarżona regulacja prowadzi do tak radykalnego ograniczenia ogółu dochodów Gminy Świecie nad Osą, że nie jest możliwe realizowanie przez nią przypisanych jej za- 
dań publicznych. Argumentacja zawarta w analizowanym piśmie procesowym ogranicza się w istocie do wskazania, że „braki w zakresie dochodów [jako konsekwencja przyjęcia kwestionowanej regulacji - uwaga K.M.-D] skutkują niemożliwością pokrycia przewidywanych wydatków przede wszystkim związanych z realizacją zadań własnych" (wniosek nr 1, s. 7).

W rezultacie Sejm stoi na stanowisku, że zarzut naruszenia zasady adekwatności wynikającej z art. 167 ust. 1 Konstytucji nie został uzasadniony zgodnie $\mathrm{z}$ wymogami płynącymi $\mathrm{z}$ art. 47 ust. 2 pkt 4 ustawy o TK i z tego względu postępowanie w zakresie badania zgodności z tym wzorcem konstytucyjnym podlega umorzeniu, na podstawie art. 59 ust. 1 pkt 2 ustawy o TK.

6. Sejm jest natomiast skłonny uznać, że wnioskodawczyni nr $1 \mathrm{w}$ sposób wystarczający dla skutecznego uruchomienia kontroli konstytucyjności wskazała w swoim wniosku argumenty przemawiające za naruszeniem przez art. 17 pkt 2 ustawy zmieniającej art. 167 ust. 3 Konstytucji. W perspektywie tego wzorca kontroli, wskazanego jako akcesoryjny względem zasad płynących z art. 2 Konstytucji, będzie więc prowadzona analiza zgodności.

7. W odniesieniu do postawionego we wniosku nr 1 zarzutu niezgodności art. 17 pkt 2 ustawy zmieniającej z wywodzonymi z art. 2 Konstytucji zasadami: ochrony praw nabytych oraz ochrony interesów w toku, Sejm podaje w wątpliwość, czy zasady te dotyczą sytuacji wnioskodawczyni nr 1 będącej organem stanowiącym jednostki samorządu terytorialnego, a także czy wnioskodawczyni nr 1 przedstawiła adekwatne argumenty na poparcie swojego wniosku. A tym samym, czy zostały wypełnione ustawowe wymagania wynikające $\mathrm{z}$ art. 47 ust. 2 pkt 4 ustawy o TK.

Trzeba bowiem zauważyć, że zgodnie z utrwalonym orzecznictwem Trybunału Konstytucyjnego, zasada ochrony praw nabytych i związana $\mathrm{z}$ nią zasada ochrony interesów w toku - niejako genetycznie - odnosi się do ochrony praw i interesów podmiotów prywatnych.

Jak podkreśla Trybunał Konstytucyjny, z zasady demokratycznego państwa prawnego, która została sformułowana w art. 2 Konstytucji, „wynika m.in. zasada lojalności państwa wobec obywatela. $\mathrm{Z}$ zasady tej Trybunał wyprowadził dalsze szczegółowe reguły, odnoszące się m.in. do sytuacji następowania po sobie zmian obowiązującego prawa. Wśród nich znajduje się reguła, która nakłada na ustawodawcę obowiązek ochrony praw nabytych i ochrony interesów będących w toku (zob. wyrok TK z 25 listopada 2010 r., sygn. K 27/09, OTK ZU nr 9/A/2010, poz. 109). Treścią zasady ochrony praw nabytych jest zapewnienie ochrony publicznych i prywatnych praw podmiotowych oraz zakaz arbitralnego znoszenia lub ograniczania praw podmiotowych, które przysługują jednostce lub innym podmiotom prywatnym występującym w obrocie prawnym. Trybunał zwrócił uwagę, że ochrona praw nabytych dotyczy praw, które zostały nabyte «słusznie», tzn. wyklucza to stosowanie analizowanej zasady w odniesieniu do praw nabytych contra legem i praeter legem oraz uzyskanych w sposób 
niedopuszczalny w demokratycznym państwie prawnym albo z naruszeniem zasady sprawiedliwości społecznej (zob. np. w wyroku TK z 24 lutego 2010 r., sygn. K 6/09, OTK ZU nr 2/A/2010, poz. 15). Ponadto, ochroną zostały objęte także ekspektatywy, czyli prawa tymczasowe, które mają charakter maksymalnie ukształtowany (zob. np. w wyroku TK z 24 października 2000 r., sygn. SK 7/00, OTK ZU nr 7/2000, poz. 256).

Tak rozumiana zasada ochrony praw nabytych, wiąże się ściśle z koncepcją praw podmiotowych i ekspektatyw maksymalnie ukształtowanych tych praw. A zatem zakres stosowania zasady praw nabytych obejmuje tylko takie przypadki, w których dana regulacja prawna stanowi źródło praw podmiotowych bądź ekspektatyw maksymalnie ukształtowanych tych praw (zob. np. w wyroku Trybunału Konstytucyjnego z 8 stycznia 2009 r., sygn. P 6/07, OTK ZU nr 1/A/2009, poz. 2). Zarzut naruszenia praw nabytych może w związku z tym być formułowany w wypadku wskazania konkretnego prawa podmiotowego (ewentualnie maksymalnie ukształtowanej ekspektatywy), które zostało odebrane lub ograniczone (por. wyrok TK z 7 listopada 2005 r., sygn. P 20/04, OTK ZU nr 10/A/2005, poz. 111)" (wyrok TK z 10 lutego 2015 r., sygn. akt P 10/11).

Jednocześnie $z$ analizy orzecznictwa Trybunału wynika, że ochrona praw nabytych nie ma charakteru bezwzględnego, a ocena dopuszczalności odstępstw od niej może być dokonana na tle konkretnej sytuacji z uwzględnieniem całokształtu okoliczności. Jako typowy przykład uzasadnienia dla naruszenia ochrony praw nabytych w orzecznictwie konstytucyjnym wskazuje się wymóg zapewnienia realizacji czy ochrony innej wartości istotnej dla systemu prawnego (ibidem). Jak wskazał Trybunał, m.in. w wyroku z 15 września 1999 r. (sygn. akt K 11/99), dopuszczalność ograniczeń nabytych praw podmiotowych wymaga a casu ad casum rozważenia, czy podstawą wprowadzonych ograniczeń są inne normy, zasady lub wartości konstytucyjne, którym w danej sytuacji należy dać pierwszeństwo; nie ma możliwości realizacji danej normy, zasady lub wartości konstytucyjnej bez naruszenia praw nabytych; wartościom konstytucyjnym, dla realizacji których prawodawca ogranicza prawa nabyte, można w danej konkretnej sytuacji przyznać pierwszeństwo przed wartościami znajdującymi się u podstaw zasady ochrony praw nabytych; prawodawca podjął niezbędne działania mające na celu zapewnienie jednostce warunków do przystosowania się do nowej regulacji (por. także wyrok TK z 17 listopada 2003 r., sygn. akt K 32/02).

Z orzecznictwa Trybunału na gruncie normatywnej konstrukcji systemu podatkowego wynika jednoznacznie, że „ustawodawca posiada w szczególności swobodę kształtowania systemu podatkowego. Konstytucja pozostawia szczególnie szeroką swobodę regulacyjną w zakresie wprowadzania i znoszenia zwolnień i ulg podatkowych. Swoboda w kształtowaniu materialnych treści prawa podatkowego jest jednak równoważona $\mathrm{z}$ istnieniem obowiązku przestrzegania konstytucyjnych standardów demokratycznego państwa prawnego. Do standardów tych należy w szczególności zasada ochrony zaufania jednostki do państwa 
i stanowionego przez nie prawa, a także ochrony praw nabytych oraz ochrony interesów w toku, które stanowią konkretyzację wymienionej zasady konstytucyjnej" (wyrok TK z 25 czerwca 2002 r., sygn. akt K 45/01). Trybunał stoi na stanowisku, że „zasada ochrony interesów w toku zapewnia ochronę jednostki w sytuacjach, w których rozpoczęła ona określone przedsięwzięcia na gruncie dotychczasowych przepisów. Chociaż zasada ta nie ma charakteru bezwzględnego, na ustawodawcy ciąży szczególny obowiązek ochrony interesów w toku w sytuacji wystąpienia następujących przesłanek: „1) przepisy prawa wyznaczają pewien horyzont czasowy dla realizowania określonych przedsięwzięć; 2) dane przedsięwzięcie ma charakter rozłożony w czasie; 3 ) jednostka faktycznie rozpoczęła realizację danego przedsięwzięcia w okresie obowiązywania danej regulacji”" (ibidem).

Obowiązkiem ustawodawcy, ze względu na ochronę interesów w toku, jest ustanowienie przepisów, „które umożliwią dokończenie przedsięwzięć rozpoczętych stosownie do przepisów obowiązujących w chwili ich rozpoczynania albo stworzą inną możliwość dostosowania się do zmienionej regulacji prawnej (zob. np. wyrok TK z 5 stycznia 1999 r., sygn. akt K 27/98, OTK ZU nr 1/1999, poz. 1)” (wyrok TK z 10 lutego 2015 r., sygn. akt P 10/11).

W świetle przywołanych obszernie wypowiedzi Trybunału trudno uznać, że jednostka samorządu terytorialnego, co istotne in casu - działająca w sferze imperium - może być uznana za beneficjenta zasady ochrony praw nabytych i interesów w toku. Należy przypomnieć, że samorząd terytorialny, w świetle art. 163 Konstytucji, jest częścią władzy publicznej, realizowanej w sposób zdecentralizowany (art. 15 Konstytucji), przejawiającej się m.in. - jak w realiach niniejszej sprawy - w sprawowaniu władztwa podatkowego. Przyznanie jednostkom samorządu terytorialnego osobowości prawnej, prawa własności i sądowej ochrony ich samodzielności należy zawsze postrzegać w perspektywie gwarancji prawidłowego wykonywania zadań publicznych (zob. wyrok TK z 20 lutego 2002 r., sygn. akt K 39/00), a nie jako uznanie ich za podmiot konstytucyjnych praw i wolności (z tego też względu Trybunał konsekwentnie odmawia zdolności skargowej jednostkom samorządu terytorialnego, zob. np. postanowienia TK z: 18 marca 2010 r., sygn. akt Ts 163/09, i 28 lipca 2009 r., sygn. akt Ts 202/08).

W dotychczasowym orzecznictwie Trybunał Konstytucyjny nie odnosił bezpośrednio do zasady ochrony praw nabytych oraz zasady ochrony interesów w toku do ochrony praw i interesów jednostek samorządu terytorialnego działających w sferze imperium (w odniesieniu do sfery dominium, zob. np. wyrok TK z 12 kwietnia 2005 r., sygn. akt K 30/03).

8. Niezależnie od poczynionych uwag krytycznych co do możliwości odnoszenia zasady ochrony praw nabytych oraz zasady ochrony interesów w toku do sytuacji jednostek samorządu terytorialnego w zakresie sprawowania przez nie władztwa podatkowego, należy wyrazić krytyczne stanowisko co do spełnienia przez wniosek nr 1 wymogu adekwatnego uzasadnienia zarzutów, które miały- 
by przemawiać za złamaniem przywołanych zasad. We wniosku tym wskazano jedynie na sprzeczność zakwestionowanej regulacji z zasadą ochrony praw nabytych oraz zasadą ochrony interesów w toku, jednak bez żadnej głębszej refleksji. W szczególności nie udowodniono, że możliwość zastosowania wyższej stawki podatku od elektrowni wiatrowej stanowiła prawo nabyte wnioskodawczyni nr 1 , w rozumieniu utrwalonym w orzecznictwie Trybunału Konstytucyjnego. Podobnie sprawa przedstawia się w odniesieniu do zasady ochrony interesów w toku.

Pamiętając, że motywy wystąpienia do Trybunału Konstytucyjnego muszą wskazywać precyzyjnie co najmniej jeden argument przemawiający za naruszeniem danego wzorca kontroli, którego to wymogu nie spełniają uwagi nazbyt ogólne, niejasne czy też czynione jedynie na marginesie innych rozważań (zob. np. wyrok TK z 5 czerwca 2014 r., sygn. akt K 35/11; postanowienia TK z: 13 stycznia 2015 r., sygn. akt K 44/13; 21 stycznia 2015 r., sygn. akt K 13/13), trzeba uznać, że uzasadnienie naruszenia omawianego wzorca kontroli nie jest wystarczające (por. wyrok TK z 28 listopada 2013 r., sygn. akt K 17/12).

Dodatkowo należy odnotować, że w podsumowaniu wniosku nr 1 znajduje się także postulat zbadania art. 17 pkt 2 ustawy zmieniającej z zasadą przyzwoitej legislacji, również wywodzoną z zasady demokratycznego państwa prawnego.

Trzeba mieć świadomość, że nakaz przestrzegania zasad poprawnej legislacji jest - zgodnie z poglądami Trybunału Konstytucyjnego - funkcjonalnie związany z zasadą nieretroakcji prawa, zasadą ochrony zaufania, bezpieczeństwa prawnego oraz pewności prawa (zob. np. wyroki TK z: 30 października 2001 r., sygn. akt K 33/00; 22 maja 2002 r., sygn. akt K 6/02; 7 stycznia 2004 r., sygn. akt K 14/03), wnioskodawczyni nr $1 \mathrm{w}$ żadnym innym miejscu wniosku oprócz podsumowania nie poświęca uwagi temu wzorcowi. Z tego względu należy uznać, że nie został spełniony pożądany w świetle ustawy o TK wymóg stosownego uzasadnienia stawianego zarzutu ani nawet rekonstrukcji treści normatywnej postulowanego wzorca.

W następstwie powyższego Sejm wnosi o umorzenie postępowania na podstawie art. 59 ust. 1 pkt 2 ustawy o TK w zakresie dotyczącym kontroli zgodności art. 17 pkt 2 ustawy zmieniającej z zasadami ochrony praw nabytych i interesów $\mathrm{w}$ toku oraz przyzwoitej legislacji, wywodzonymi z art. 2 Konstytucji, ze względu na niedopuszczalność wydania wyroku.

9. Podsumowując część stanowiska poświęconą analizie formalnoprawnej, należy wskazać, że uwzględniając korektę w zakresie przedmiotu kontroli oraz partykularnych wniosków o umorzenie postępowania, analizą zgodności objęty jest art. 17 ust. 2 ustawy zmieniającej w perspektywie wywodzonych $\mathrm{z}$ art. 2 Konstytucji zasad: nieretroakcji prawa, ochrony zaufania do państwa i stanowionego przez nie prawa (pewności prawa), zakazu zmiany prawa podatkowego $\mathrm{w}$ trakcie trwania roku podatkowego w związku z art. 167 ust. 3 Konstytucji (zasada samodzielności finansowej jednostek samorządu terytorialnego). 


\section{Analiza merytoryczna}

\section{- 1. Wzorce kontroli}

1. Podstawowym wzorcem kontroli jest w analizowanej sprawie art. 2 Konstytucji w brzmieniu: „Rzeczpospolita Polska jest demokratycznym państwem prawnym, urzeczywistniającym zasady sprawiedliwości społecznej”.

W treści art. 2 Konstytucji zostały wyrażone trzy zasady konstytucyjne: zasada państwa demokratycznego, zasada państwa prawnego oraz zasady sprawiedliwości społecznej. W odniesieniu do zasady państwa prawnego w doktrynie wyrażono pogląd, że „w związku z rolą, jaką odgrywa klauzula państwa prawnego dla ustrojowej charakterystyki państwa polskiego, jej wpływ na normatywną treść Konstytucji RP oraz oddziaływanie na płaszczyznę stanowienia i stosowania prawa można postawić pytanie: czy jest ona konstytucyjną klauzulą wiodącą, "zasadą-kluczem», klauzulą, z której należy wyprowadzać cały porządek konstytucyjny? Wydaje się że taką rolę klauzula państwa prawnego spełniała do 1997 r. Obecnie pełni ona nadal tę rolę w odniesieniu do formalnego aspektu państwa prawnego, w szczególności do płaszczyzny stanowienia prawa. W odniesieniu do aspektu materialnego należy stwierdzić, że obecnie ani doktryna, ani TK nie wywodzą nowych praw konstytucyjnych z art. 2 Konstytucji RP. Dla normatywnej treści wolności i praw człowieka kluczowe znaczenie ma natomiast obecnie art. 30 Konstytucji RP. To w zasadzie nienaruszalnej i niezbywalnej godności człowieka tkwi największy potencjał dla wydobywania z Konstytucji RP praw człowieka, dookreślania treści praw w ustawie zasadniczej wyrażonych oraz interpretowania konstytucyjnych klauzul limitacyjnych (L. Garlicki, Wolności i prawa jednostki, s. 63 i n.)" (P. Tuleja, Komentarz do art. 2 [w:] Konstytucja RP. Komentarz, t. I, Art. 1-86, red. M. Safjan, L. Bosek, Warszawa 2016, nb. 47).

Wnioskodawczynie zarzucają sprzeczność zaskarżonego przepisu ze szczegółowymi zasadami wywodzonymi z zasady demokratycznego państwa prawnego, a mianowicie z zasadami: ochrony zaufania do państwa i stanowionego przez nie prawa (pewności prawa), bezpieczeństwa prawnego, niezmieniania prawa podatkowego w ciągu roku podatkowego, a przede wszystkim zasadą niedziałania prawa wstecz.

2. Odczytując treść zasady nieretroakcji, Trybunał wskazał, że: „Zasada niedziałania prawa wstecz była wielokrotnie przedmiotem rozważań Trybunału Konstytucyjnego. Przekrojowej analizy wcześniejszego orzecznictwa odnoszącego się do zasady lex retro non agit Trybunał dokonał w wyroku z 3 października 2001 r. (sygn. K 27/01, OTK ZU nr 7/2001, poz. 209). W orzeczeniu tym Trybunał przypomniał, że zasada ta, będąca istotnym elementem systemów prawnych współczesnych państw demokratycznych, ma swoje korzenie w starożytności. W prawie rzymskim funkcjonowała już na gruncie Kodeksu Justyniana. W polskim porządku prawnym zasada lex retro non agit była przywołana już w XIV w. Była uznaną zasadą systemu prawnego II Rzeczypospolitej. 
W orzecznictwie Trybunału Konstytucyjnego utrzymuje się konsekwentnie jednolita linia rozumienia znaczenia zakazu retroaktywnego działania ustanowionej normy. W wyroku z 30 listopada 1988 r. (sygn. akt K 1/88, OTK w 1988 r., poz. 6, s. 81) Trybunał stwierdził, że: „Zasadę niedziałania prawa wstecz TK rozumie szerzej, nie tylko jako zakaz stanowienia norm prawnych, które nakazywałyby stosować nowo ustanowione normy prawne do zdarzeń, które miały miejsce przed ich wejściem w życie i z którymi prawo nie wiązało dotąd skutków prawnych (zasada lex retro non agit we właściwym tego słowa znaczeniu), lecz także jako zakaz stanowienia intertemporalnych reguł, które mają określić treść stosunków prawnych powstałych pod rządami dawnych norm, a trwających w okresie wejścia w życie norm nowo ustanowionych, jeżeli reguły te wywołują ujemne prawne (a w konsekwencji społeczne) następstwa dla bezpieczeństwa prawnego i poszanowania praw nabytych. [...] zasada zaufania do państwa wymaga, by mocy wstecznej nie nadawać przepisom, które regulują prawa i obowiązki obywateli i pogarszają ich sytuację prawną".

Pod rządami Konstytucji z 2 kwietnia 1997 r. Trybunał wielokrotnie przypominał, że „zgodnie z utrwaloną linią orzeczniczą Trybunału Konstytucyjnego zasada niedziałania prawa wstecz stanowi podstawę porządku prawnego. Kształtuje zasadę zaufania obywateli do państwa oraz stanowionego przez nie prawa. U podstaw tejże zasady leży wyrażona w art. 2 Konstytucji zasada demokratycznego państwa prawnego" (wyrok TK z 17 grudnia 1997 r., sygn. akt K 22/96). Trybunał Konstytucyjny podkreślał też, że „zasada lex retro non agit oraz zasada ochrony praw słusznie nabytych mają charakter zasad przedmiotowych, wyznaczających granice ingerencji władzy publicznej w sferę praw podmiotowych. Naruszenie tych zasad może uzasadniać zarzut niedopuszczalnego wkroczenia przez tę władzę w sferę konstytucyjnie chronionych praw lub wolności jednostki, co $\mathrm{w}$ konsekwencji prowadzi do stwierdzenia sprzecznego z porządkiem konstytucyjnym naruszenia tych praw lub wolności" (postanowienie TK z 17 lutego 1999 r., sygn. akt Ts 154/98). Trybunał stwierdzał też, że odstępstwo od zakazu retroaktywności jest dopuszczalne w szczególności wtedy, gdy „jest to konieczne dla realizacji wartości konstytucyjnej, ocenionej jako ważniejsza od wartości chronionej zakazem retroakcji” (wyrok TK z 31 stycznia 2001 r., sygn. akt P 4/99). Działanie prawa wstecz „nie oznacza naruszenia art. 2 Konstytucji, o ile tak wprowadzone przepisy polepszają sytuację prawną niektórych adresatów danej normy prawnej i zarazem nie pogarszają sytuacji prawnej pozostałych jej adresatów (por. [...] wyrok TK z 25 września 2000 r., sygn. akt K 26/99, OTK ZU nr 6/2000, poz. 186)” (wyrok TK z 8 marca 2005 r., sygn. akt K 27/03).

„Zgodnie z utrwalonym orzecznictwem Trybunału Konstytucyjnego zasada lex retro non agit, wywodzona obecnie $\mathrm{z}$ art. 2 Konstytucji, stanowi istotny składnik zasady demokratycznego państwa prawnego. Zasada niedziałania prawa wstecz wymaga, aby nie stanowić prawa, które nakazuje stosowanie nowo ustanowionych norm do sytuacji, które miały miejsce przed ich wejściem w życie. 
Odstępstwa od tej zasady dopuszczalne są w wyjątkowych okolicznościach, jeżeli przemawia za tym konieczność realizacji innej zasady konstytucyjnej, a realizacja tej zasady nie jest możliwa bez wstecznego działania prawa. Dopuszczalność odstępstwa od tej zasady zależy również od wagi wartości konstytucyjnych, które badana regulacja ma chronić (por. wyrok z 7 lutego 2001 r., sygn. K 27/00)" (wyrok TK z 20 stycznia 2010 r., sygn. akt Kp 6/09).

3. Jako wzorzec kontroli wnioskodawczynie wskazują zasadę ochrony zaufania jednostki samorządu terytorialnego do państwa i stanowionego przez nie prawa. Należy więc przypomnieć, że pomimo dyskusyjności zagadnienia czy i na ile jednostka samorządu terytorialnego może być uznawana za beneficjenta przywołanej zasady (por. wyrok TK z 25 maja 1998 r., sygn. akt U 19/97), Trybunał Konstytucyjny w nowszym orzecznictwie jednoznacznie zaaprobował ją jako wiążącą również w stosunkach między jednostkami samorządu terytorialnego a państwem (zob. wyroki TK z: 18 lipca 2006 r., sygn. akt U 5/04; 29 października 2010 r., sygn. akt P 34/08).

Trybunał Konstytucyjny wielokrotnie podkreślał, że zasada ochrony zaufania funkcjonalnie odnosi się zarówno do stanowienia, jak i do stosowania prawa przez organy władzy publicznej. Zgodnie z orzecznictwem konstytucyjnym dotyczącym zasady ochrony zaufania jednostki do państwa i stanowionego przez nie prawa, istota tej zasady sprowadza się do nakazu takiego stanowienia i stosowania prawa, by obywatel mógł układać swoje sprawy w zaufaniu, że nie naraża się na skutki prawne, których nie mógł przewidzieć w momencie podejmowania decyzji (zob. wyroki TK z: 2 czerwca 1999 r., sygn. akt K 34/98; 10 kwietnia 2001 r., sygn. akt U 7/00; 19 kwietnia 2005 r., sygn. akt K 4/05; 15 lutego 2005 r., sygn. akt K 48/04; 31 stycznia 2006 r., sygn. akt K 23/03).

Jak wskazał sąd konstytucyjny, „zasada zaufania społeczności lokalnej jednostki samorządu terytorialnego do państwa i stanowionego przez nie prawa, analogicznie do zasady zaufania obywateli do państwa i stanowionego przez nie prawa w ogólności, opiera się na pewności prawa, a więc takim zespole cech przysługujących prawu, które zapewniają bezpieczeństwo prawne oraz umożliwiają jednostkom samorządu terytorialnego decydowanie o swoim postępowaniu w oparciu o pełną znajomość treści obowiązującego tekstu prawnego oraz przesłanek działania organów państwowych i konsekwencji prawnych, jakie ich działania mogą wywołać (zob. wyrok TK z 18 lipca 2006 r., sygn. U 5/04)” ( wyrok TK z 31 stycznia 2013 r., sygn. akt K 14/11).

Jednocześnie jednak Trybunał podkreśla, że odczytywanie zasady zaufania jednostki samorządu terytorialnego do państwa i stanowionego przez nie prawa, ze względu na przynależność samorządu terytorialnego do sfery władzy publicznej, powinno być dokonywane z uwzględnieniem zasad lojalnej współpracy, zakładającej obustronne zaufanie między państwem a jednostkami samorządu terytorialnego (zob. wyrok TK z 12 marca 2007 r., sygn. akt K 54/05). 
W świetle wypowiedzi Trybunału, „zasada zaufania obywatela do państwa i stanowionego przez nie prawa opiera się na pewności prawa, a więc takim zespole cech przysługujących prawu, które zapewniają jednostce bezpieczeństwo prawne; umożliwiają jej decydowanie o swoim postępowaniu w oparciu o pełną znajomość przesłanek działania organów państwowych oraz konsekwencji prawnych, jakie jej działania mogą pociągnąć za sobą. Jednostka winna mieć możliwość określenia zarówno konsekwencji poszczególnych zachowań i zdarzeń na gruncie obowiązującego w danym momencie systemu, jak też oczekiwać, że prawodawca nie zmieni ich w sposób arbitralny. Bezpieczeństwo prawne jednostki związane z pewnością prawa umożliwia więc przewidywalność działań organów państwa, a także prognozowanie działań własnych" (wyrok TK z 14 czerwca 2000 r., sygn. akt P 3/00).

4. Kolejną z zasad wydobywanych $\mathrm{z}$ art. 2 Konstytucji w charakterze wzorca kontroli w niniejszej sprawie jest zakaz zmiany prawa podatkowego $\mathrm{w}$ trakcie trwania roku podatkowego. W odniesieniu do legislacji podatkowej Trybunał Konstytucyjny wyraził bowiem pogląd, że w dotychczasowym orzecznictwie wskazywano już, iż „nie jest w zasadzie dopuszczalne dokonywanie zmian obciążeń podatkowych w ciągu roku (orzeczenie z 29 marca 1994 r., K. 13/93, OTK w 1994 r., cz. I, s. 49-50). Zmiany takie, gdy chodzi o obecne ukształtowanie podatku dochodowego od osób fizycznych, «powinny wchodzić w życie przynajmniej na miesiąc przed końcem poprzedniego roku podatkowego (orzeczenie z 28 grudnia 1995 r., K. 28/95, OTK ZU Nr 3/1995, s. 204-205). Nie są to wprawdzie wymagania o bezwzględnie wiążącym charakterze, ale odstąpienie od nich dopuszczalne jest tylko, gdy przemawiają za tym uzasadnione argumenty prawne» (tamże, s. 448-449). [...] Trybunał w swoim orzecznictwie nie wyrażał nigdy stanowiska o absolutnym charakterze zakazu zmian w prawie podatkowym w ciągu roku podatkowego, w szczególności tam gdzie chodzi o cofnięcie ulg lub przywilejów. Zmiany takie zawsze jednak powinny być usprawiedliwione balansowaniem wchodzących w grę wartości konstytucyjnych" (wyrok TK z 25 kwietnia 2001 r., sygn. akt K 13/01).

5. Akcesoryjnym - względem art. 2 Konstytucji - wzorcem kontroli w niniejszej sprawie, w świetle woli wyrażonej przez Radę Gminy Świecie nad Osą, jest art. 167 ust. 3 Konstytucji: „Źródła dochodów jednostek samorządu terytorialnego są określone w ustawie". Przepis ten stanowi jeden z normatywnych wyrazów samodzielności finansowej jednostek samorządu terytorialnego. W doktrynie podkreśla się, że „Samodzielność finansowa j.s.t. podniesiona została do rangi konstytucyjnej w art. 167, który zawiera gwarancję zapewnienia samorządowi terytorialnemu udziału $\mathrm{w}$ dochodach publicznych odpowiednio do przypadających zadań (tzw. zasada adekwatności), stanowi o poszczególnych rodzajach dochodów samorządu oraz źródłach normatywnych, w których powinny one zostać określone. Przepis ten został określony w doktrynie mianem «konstytucji finansowej samorządu» ze względu na to, że definiuje zasady wyposażania 
j.s.t. w dochody" (A. Skoczylas, W. Piątek, Komentarz do art. 167 [w:] Konstytucja RP. Komentarz, t. II, Art. 87-243, red. M. Safjan, L. Bosek, Warszawa 2016, nb. 1).

Dokonując rekonstrukcji wzorca wynikającego z art. 167 ust. 3 Konstytucji, Trybunał wywiódł, że „zasada samodzielności finansowej gminy znajduje obecnie konstytucyjny wyraz m.in. w art. 167 ust. 3 wskazującym, iż «źródła dochodów jednostek samorządu terytorialnego są określone w ustawie». [...] Trybunał Konstytucyjny uważa, że unormowaniu zawartemu w art. 167 ust. 3 konstytucji przypisać należy dwojakie znaczenie prawne. Przede wszystkim traktować go należy jako przepis gwarantujący gminom odpowiedni poziom dochodów, pozwalający im na realizację konstytucyjnie wyznaczonych zadań (a przypomnieć należy, że - w myśl ogólnej zasady konstytucyjnej, wyrażonej w art. 16 ust. 2 samorządowi terytorialnemu przysługiwać ma istotna część zadań publicznych, a zadania te samorząd ma wykonywać w imieniu własnym i na własną odpowiedzialność), a także zastrzegający formę ustawy dla określania źródeł tych dochodów. Oznacza to, że na poziomie ustawowym muszą zostać sformułowane wszystkie rozstrzygnięcia podstawowe dla wyznaczenia rodzaju i charakteru prawnego poszczególnych źródeł dochodów, a tym samym - także rozstrzygnięcia wyznaczające sposób ustalania wysokości tych dochodów. Innymi słowy, ogólny poziom dochodów jednostki samorządu terytorialnego musi być możliwy do ustalenia już na podstawie regulacji ustawowej, czyli regulacja ta musi zachowywać odpowiedni stopień precyzji i szczegółowości, a nie może ograniczać się do blankietowych odesłań do regulacji wykonawczych.

Trybunał Konstytucyjny uważa jednak, że na tym nie wyczerpuje się znaczenie prawne art. 167 ust. 3, zwłaszcza gdy przepis ten interpretować w powiązaniu tak $\mathrm{z}$ art. 16, jak i z pozostałymi postanowieniami rozdziału VII konstytucji. Ustawowe zagwarantowanie źródeł dochodów pełni bowiem rolę instrumentalną wobec celu podstawowego, jakim jest zapewnienie jednostce samorządu terytorialnego (gminie) odpowiednich środków finansowych na realizację jej zadań. Art. 167 ust. 3 można więc traktować jako wyraz zasady ogólniejszej, gwarantującej gminie nie tylko pozostawienie do jej dyspozycji określonych środków finansowych (poprzez zagwarantowanie źródeł, z których wypływają), ale też gwarantującej gminie możliwość samodzielnego wykorzystywania tych środków, a tym samym dokonywania wydatków i kształtowania za ich pomocą zadań. Gdyby bowiem wykluczyć istnienie konstytucyjnych gwarancji dla samodzielności dokonywania wydatków, to ustawowe zagwarantowanie źródeł dochodów, a także samodzielnego wykonywania zadań, mogłoby okazać się iluzoryczne, bo pozyskane środki finansowe mogłyby być gminie odbierane bez jakichkolwiek ograniczeń" (wyrok TK z 24 marca 1998 r., sygn. akt K 40/97).

Należy nadto przypomnieć, w ślad za poglądami Trybunału Konstytucyjnego, że samodzielność finansowa jednostek samorządu terytorialnego nie ma charakteru absolutnego. Może ona zostać ograniczona w drodze ustawy pod warun- 
kiem, że owe ograniczenia znajdują uzasadnienie w konstytucyjnie określonych celach i chronionych wartościach. W ocenie Trybunału Konstytucyjnego „eliminacji określonych źródeł dochodów własnych nie można mylić z ich modyfikacjami, nawet gdy rezultat danej modyfikacji jest niekorzystny dla finansów gmin. Dopóki ustawodawca w sposób drastyczny nie naruszy samej istoty samodzielności finansowej gminy, przysługuje mu - pod warunkiem poszanowania innych norm, zasad i wartości konstytucyjnych daleko idąca swoboda w określaniu zarówno źródeł dochodów gmin, jak też poziomu tych dochodów” (wyrok TK z 15 grudnia 1997 r., sygn. akt K 13/97; zob. także wyrok TK z 3 listopada 1998 r., sygn. akt K 12/98).

\section{- 2. Analiza zgodności}

1. Przechodząc do merytorycznej oceny zarzutów sformułowanych w pismach inicjujących postępowanie w sprawie o sygn. akt K 4/19, uwzględniając korektę w zakresie przedmiotu kontroli oraz partykularnych wniosków o umorzenie postępowania, należy stwierdzić, co następuje.

Sejm zgadza się z tezą postawioną przez Radę Gminy Kobylnica, że ustawodawca z pełną świadomością zdecydował się na przyjęcie regulacji w kwestionowanym kształcie, czyli z zastosowaniem mechanizmu retroakcyjnego (wniosek nr 2, s. 19), jednakże nie podziela argumentów wnioskodawczyni nr 2, odnoszących się do tego, że zabieg ten nie był podyktowany żadną z wartości konstytucyjnych, którą należałoby chronić.

Wnioskodawczyni nr 2 formułuje w swoim wniosku twierdzenie o braku związku z którąkolwiek z poszczególnych wartości i zasad zakotwiczonych w Konstytucji, dodając: „w niniejszej sprawie nie sposób wskazać okoliczności, które w świetle orzecznictwa Trybunału Konstytucyjnego usprawiedliwiałyby odstępstwo od zasady lex retro non agit. W szczególności Rada Gminy Kobylnica nie zna (nie jest świadoma istnienia) zasady konstytucyjnej, której ochrona czy urzeczywistnienie uzasadniałoby wprowadzenie przepisu art. 17 pkt 2 Ustawy Nowelizującej" (wniosek nr 2, s. 15).

Analogiczne zastrzeżenie zgłoszono we wniosku nr 1, podkreślając, że badana regulacja została przyjęta przy jednoczesnym braku wskazania w uzasadnieniu ustawy zmieniającej wartości konstytucyjnej, która usprawiedliwiałaby zdiagnozowaną retroakcję (wniosek nr 1, s. 5).

Sejm jest skłonny uznać, że przedstawiona przez wnioskodawczynie argumentacja spełnia warunki formalne wymagane do zainicjowania postępowania przed sądem konstytucyjnym. Zarazem jednak pragnie wyrazić przekonanie, że podnoszony przez nie brak wykazania konstytucyjnej przesłanki zastosowania mechanizmu retroakcji w uzasadnieniu projektu ustawy zmieniającej, która wprowadziła sporne regulacje, nie przesądza o niekonstytucyjności przyjętego rozwiązania. Szczegółowość uzasadnienia projektu ustawy, zwłaszcza w przypadku aktów o znacznej obszerności, jest pozostawiona bowiem uznaniu usta- 
wodawcy, a spełnienie wymagań formalnych w tym zakresie jest na początku procesu legislacyjnego weryfikowane przez Marszałka Sejmu (zob. art. 34 ust. 7 uchwały Sejmu Rzeczypospolitej Polskiej z 30 lipca 1992 r. - Regulamin Sejmu Rzeczypospolitej Polskiej; t.j. M.P. 2019, poz. 1028, ze zm.).

Poza sporem w niniejszej sprawie jest to, że ustawodawca zdecydował się na zastosowanie mechanizmu retroakcji, bowiem $\mathrm{w}$ kwestionowanym przepisie wprost przewidział, że art. 2 pkt 1 i 6 oraz art. 3 pkt 1 wchodzą w życie z dniem następującym po dniu ogłoszenia ustawy zmieniającej, tj. 29 czerwca 2018 r., z mocą od dnia 1 stycznia $2018 \mathrm{r}$. Tym samym definicja obiektu budowlanego $\mathrm{w}$ odniesieniu do elektrowni wiatrowych na potrzeby ustalenia przedmiotu opodatkowania podatkiem od nieruchomości powinna być stosowana względem stanów faktycznych już od 1 stycznia 2018 r.

2. Dla przedstawienia ratio takiej decyzji prawodawczej należy pokrótce przedstawić zasady rządzące opodatkowaniem elektrowni wiatrowych podatkiem od nieruchomości.

Podatek ten od 26 września 2005 r. do 1 stycznia 2017 r. kształtowały przepisy ustawy z 7 lipca 1994 r. - Prawo budowane (t.j. Dz. U. 2019, poz. 1186, ze zm.; dalej: u.p.b.) oraz ustawy o podatkach i opłatach lokalnych. W orzecznictwie Naczelnego Sądu Administracyjnego (dalej: NSA) w stanie prawnym obowiązującym w przywołanym okresie przyjmowano, że budowlą w rozumieniu ustawy o podatkach i opłatach lokalnych są wyłącznie części budowlane urządzenia technicznego, jakim jest elektrownia wiatrowa. W związku z tym do podstawy opodatkowania podatkiem od nieruchomości nie wliczano wartości generatora, rotora z gondolą, wirnika, generatora, skrzyni biegów, komputera sterującego, transformatora, rozdzielni energetycznej, instalacji alarmowej zdalnego sterowania (zob. wyroki NSA z: 15 maja 2012 r., sygn. akt II FSK 2132/10; 5 stycznia 2010 r., sygn. akt II FSK 1101/08; 2 grudnia 2011 r., sygn. akt II FSK 1658/10; 30 lipca 2009 r., sygn. akt II FSK 202/08; 7 października 2009 r., sygn. akt II FSK 635/08; 16 grudnia 2009 r., sygn. akt II FSK 1184/08; 20 stycznia 2012 r., sygn. akt II FSK 1397/10). Orzecznictwo uznawało, że budowlą, stanowiącą przedmiot opodatkowania podatkiem od nieruchomości jest w związku z tym wyłącznie fundament i wieża.

Stan ten zmienił się wraz z wejściem w życie ustawy z 20 maja 2016 r. o inwestycjach w zakresie elektrowni wiatrowych (t.j. Dz. U. 2020, poz. 981). Jej mocą zmianie uległ art. 3 pkt 3 u.p.b., zawierający definicję budowli. W wyniku tej nowelizacji elektrownia wiatrowa w całości uznawana była za budowlę, a w konsekwencji podstawę opodatkowania podatkiem od nieruchomości stanowiła wartość całego wiatraka, zarówno jego części budowlanych, jak i technicznych. Regulacja ta zaczęła obowiązywać od 1 stycznia 2017 r. Ustalając wysokość stawki podatku od nieruchomości, organy jednostek samorządu terytorialnego, prowadząc własną politykę podatkową, brały więc pod uwagę wartość całego wiatraka. Efektem funkcjonowania takiego unormowania było z jednej strony zwiększe- 
nie dochodów jednostek samorządu terytorialnego w 2017 r., z drugiej jednak wzrost obciążeń podatkowych podmiotów prowadzących elektrownie wiatrowe. Wedle szacunków, w wyniku przywołanej zmiany, w przypadku przeciętnego wiatraka kwota podatku wzrosła z 20 tys. zł do 60-80 tys. zł rocznie i zgodnie $\mathrm{z}$ doniesieniami prasowymi, mieliśmy do czynienia $\mathrm{z}$ różnymi formami wymuszonego nierentownością przedsięwzięcia zakończenia prowadzenia działalności gospodarczej przez podmioty prowadzące elektrownie wiatrowe (https://www. gramwzielone.pl/energia-wiatrowa/27369/bankructwa-wlascicieli-wiatrakow-sa-faktem) lub brakiem zainteresowania w dalsze inwestycje w zakresie rozwijania odnawialnych źródeł energii, na co zwróciła uwagę Najwyższa Izba Kontroli w swojej informacji o wynikach kontroli „Rozwój sektora odnawialnych źródeł energii” z 15 listopada 2018 r. (https:/ /www.nik.gov.pl/pliklid, 18357, vp,20955. pdf, s. 15 i 41).

Dla uzupełnienia warto dodać, że taki scenariusz, zgodnie z którym doszło do wzrostu obciążeń podatkowych $\mathrm{z}$ tytułu opodatkowania elektrowni wiatrowych podatkiem od nieruchomości, nie był zamierzeniem autorów poselskiej inicjatywy dotyczącej przyjęcia ustawy o inwestycjach w zakresie elektrowni wiatrowych. Objęcie definicją budowli całego wiatraka (jego części budowlanych oraz technicznych) miało być ukierunkowane na podniesienie poziomu bezpieczeństwa funkcjonowania elektrowni wiatrowych poprzez odpowiednie rozszerzenie właściwości organów nadzoru budowlanego na całość konstrukcji. Wynikało to wprost z uzasadnienia projektu ustawy o inwestycjach w zakresie elektrowni wiatrowych: „W projekcie ustawy zaproponowano wykreślenie przepisu wprowadzającego podział elektrowni wiatrowych na części budowlaną i niebudowlaną. W proponowanym stanie prawnym cała elektrownia wiatrowa będzie obiektem budowlanym (budowlą), a tym samym zastosowanie do niej będą znajdować przepisy Prawa budowlanego dotyczące użytkowania obiektów budowlanych oraz dotyczących katastrof budowlanych" (druk sejmowy nr 315/ VIII kad.). Tymczasem w efekcie przyjętego rozwiązania doszło do wskazania jako przedmiot opodatkowania podatkiem od nieruchomości całego wiatraka, zarówno jego części budowlanej, jak i technicznej. Dawało to jednostkom samorządu terytorialnego podstawę do pobierania podatku od wartości całego wiatraka, co nawet przy niezmienionej stawce podatku od nieruchomości skutkowało zwiększonymi obciążeniami publicznoprawnymi dla przedsiębiorców prowadzących elektrownie wiatrowe.

3. Niezależnie od powyższego, rezultat w postaci zagrożenia płynności finansowej, a w efekcie upadłości producentów energii wytwarzanej przez wiatraki lub zahamowania nowych inwestycji, stanowi niepożądany stan z perspektywy zobowiązań międzynarodowych Polski, związanych z członkostwem w Unii Europejskiej (zob. art. 9 Konstytucji).

Wspólne ramy dla promowania energii ze źródeł odnawialnych w UE ustanawia dyrektywa Parlamentu Europejskiego i Rady 2009/28/WE z 23 kwietnia 
2009 r. w sprawie promowania stosowania energii ze źródeł odnawialnych zmieniająca i w następstwie uchylająca dyrektywy 2001/77/WE oraz 2003/30/WE (Dz. Urz. UE L 140 z 5 czerwca 2009 r., s. 16; dalej: dyrektywa 2009/28/WE). Zgodnie z jej art. 1, akt ten określa obowiązkowe krajowe cele ogólne w odniesieniu do całkowitego udziału energii ze źródeł odnawialnych w końcowym zużyciu energii brutto i w odniesieniu do udziału energii ze źródeł odnawialnych $\mathrm{w}$ transporcie.

W świetle art. 3 ust. 1 dyrektywy 2009/28/WE każde państwo członkowskie dba o to, aby jego udział energii ze źródeł odnawialnych w końcowym zużyciu energii brutto w 2020 r. odpowiadał co najmniej jego krajowemu celowi ogólnemu dla udziału energii ze źródeł odnawialnych w tym roku. W przypadku Polski, zgodnie z załącznikiem I część A do tej dyrektywy, cel krajowy wynosi 15\% udziału energii ze źródeł odnawialnych w końcowym zużyciu energii brutto w Polsce w 2020 r. Osiągnięcie celów wiążących powinno nastąpić poprzez stały wzrost udziału energii ze źródeł odnawialnych, aż do osiągnięcia poziomu zaplanowanego na rok 2020. Państwa członkowskie powinny wypełniać obowiązki określone w art. 3 dyrektywy 2009/28/WE poprzez wdrożenie środków skutecznie zaprojektowanych, przy czym państwa te mają obowiązek znaleźć się na orientacyjnej ścieżce wyznaczonej zgodnie z załącznikiem I część B albo osiągać wyższy udział (art. 3 ust. 2 dyrektywy 2009/28/WE). Dyrektywa ta traci moc ze skutkiem od 1 lipca 2021 r., ze względu na przyjęcie nowej dyrektywy Parlamentu Europejskiego i Rady (UE) 2001/2018 z 11 grudnia 2018 r. w sprawie promowania stosowania energii ze źródeł odnawialnych (Dz. Urz. UE L 328 z 21 grudnia 2018 r., s. 82), która wyznacza nową perspektywę temporalną wspierania rozwoju odnawialnych źródeł energii. Zgodnie z art. 3 przywołanej dyrektywy państwa członkowskie wspólnie zapewniają, aby udział energii ze źródeł odnawialnych w Unii w końcowym zużyciu energii brutto w 2030 r. wynosił co najmniej 32\%. Jednocześnie każde z państw członkowskich, w celu realizacji celu unijnego, ma obowiązek określić swój wkład krajowy w swoim zintegrowanym planie krajowym w dziedzinie energii i klimatu, zgodnie z art. 3-5 i 9-14 rozporządzenia Parlamentu Europejskiego i Rady (UE) 2018/1999 w sprawie zarządzania unią energetyczną i działaniami w dziedzinie klimatu, zmiany rozporządzeń Parlamentu Europejskiego i Rady (WE) nr 663/2009 i (WE) nr 715/2009, dyrektyw Parlamentu Europejskiego i Rady 94/22/WE, 98/70/WE, 2009/31/WE, 2009/73/WE, 2010/31/UE, 2012/27/UE i 2013/30/UE, dyrektyw Rady 2009/119/ WE i (EU) 2015/652 oraz uchylenia rozporządzenia Parlamentu Europejskiego i Rady (UE) nr 525/2013 (Dz. Urz. UE L 328 z 21 grudnia 2018 r., s. 1). Realizując to zobowiązanie, Polska w „Krajowym planie na rzecz energii i klimatu na lata 2021-2030. Założenia i cele oraz polityki i działania”, przyjętym przez Komitet do Spraw Europejskich 18 grudnia 2019 r., wyznaczyła jako jeden z celów klimatyczno-energetycznych na rok 2030: 21-23\% udziału odnawialnych źródeł energii w finalnym zużyciu energii brutto (https://www.gov.pl/web/aktywa-pan- 
stwowe/krajowy-plan-na-rzecz-energii-i-klimatu-na-lata-2021-2030-przekazany-do-ke).

Elektrownie wiatrowe stanowią istotny komponent źródła tzw. zielonej energii, a redukcja liczby elektrowni wiatrowych czy ograniczenie inwestycji w dalszych ich rozwój z całą pewnością nie przyczyni się do uzyskania pożądanego udziału energii ze źródeł odnawialnych. Brak wypełnienia powyższego zobowiązania skutkować może znaczącymi kosztami związanymi z transferem statystycznym energii z odnawialnych źródeł energii z państw członkowskich, które mają nadwyżkę, na co uwagę zwróciła Najwyższa Izba Kontroli w cytowanej informacji o wynikach kontroli „Rozwój sektora odnawialnych źródeł energii”.

Ponadto, w perspektywie przyjęcia ustawy o inwestycjach w zakresie elektrowni wiatrowych, nie jest wykluczone występowanie przez właścicieli elektrowni wiatrowych z roszczeniami w zakresie odszkodowań względem Skarbu Państwa, co również należy uznać za zagrożenie dla interesu publicznego i finansowego państwa. Zatem, w świetle powyższego, zmiana prawa w czerwcu 2018 r. ze skutkiem od 1 stycznia 2018 r. (art. 17 pkt 2 ustawy zmieniającej) miała także na celu ochronę Skarbu Państwa przed koniecznością wypłaty odszkodowań w przypadku uznania roszczeń ze strony inwestorów (właścicieli farm wiatrowych) z racji na ich nierówne traktowanie pod kątem podatkowym względem producentów pozostałych odnawialnych źródeł energii (biogaz, fotowoltaika, hydroenergetyka). Żaden z wytwórców przywołanych źródeł energii nie był bowiem zobowiązany do płacenia podatków od nieruchomości za urządzenia techniczne służące prowadzeniu działalności gospodarczej w zakresie wytwarzania energii ze źródeł odnawialnych.

Niezależnie od powyższego, troska o kondycję i utrzymanie odnawialnych źródeł energii w opinii Sejmu wynika także z zadania płynącego względem władz publicznych z art. 5 Konstytucji. Przepis ten przewiduje m.in., że Rzeczpospolita Polska zapewnia ochronę środowiska, kierując się zasadą zrównoważonego rozwoju.

4. Ponadto Sejm uznaje za nader przekonujące argumenty, jakimi posłużył się Minister Energii w piśmie z 16 września 2019 r. (dalej: pismo ME) skierowanym do zastępcy składu orzekającego Trybunału Konstytucyjnego w niniejszej sprawie, w którym wskazał on, że:

„Należy ponadto zaznaczyć, że przedmiotowa nowelizacja [art. 17 pkt 2 ustawy zmieniającej - uwaga K.M.-D.] związana była również z wykonaniem zobowiązań unijnych. Zgodnie z treścią decyzji Komisji Europejskiej w sprawie State aid SA.43697 (2015/N) - Poland - Polish support scheme for RES and relief for energy-intensive users (Załącznik nr 1) (Ustawa o odnawialnych źródłach energii - aukcyjny system wsparcia OZE oraz ulgi w opłacie OZE dla przedsiębiorstw energochłonnych) z dnia 13 grudnia 2017 r., sygnatura SG-Greffe(2017)D/19933 (w motywie 152) władze polskie zobowiązały się, że polski rząd dołoży wszelkich starań, aby zapewnić wejście w życie nowelizacji ustawy OZE - w tym zmia- 
ny podatku od nieruchomości - nie później niż 1 stycznia 2018 r., na zasadach obowiązujących przed dniem 1 stycznia 2017 r. Ponadto, w toku postępowania przed Dyrekcją Generalną do spraw Konkurencji Komisji Europejskiej w sprawie aukcyjnego mechanizmu wsparcia odnawialnych źródeł energii, zakończonego wydaniem ww. decyzji z dnia 13 grudnia 2017 r., Prezes Urzędu Ochrony Konkurencji i Konsumentów przekazał Ministrowi Energii formalną skargę złożoną przez inwestorów OZE, dotyczącą, w szczególności, niezgodnej z rynkiem wewnętrznym pomocy publicznej związanej ze zróżnicowanym traktowaniem farm wiatrowych na gruncie przepisów dotyczących podatku od nieruchomości (pismo DG COMP z dnia 24 maja 2017 r. B2/AB/MGA/ad D²017/050536 w sprawie SA.48045 (2017/FC) - Complaint concerning certain elements ofthe Polish support to RES producers). Powyższa skarga miała istotny wpływ na przebieg postępowania notyfikacyjnego w sprawie SA.43697, znacznie je wydłużając, skutkiem czego zachodziła poważna obawa, że nowelizacji nie da się uchwalić w 2017 r. W konsekwencji skargi inwestorów OZE z Komisją Europejską zostały uzgodnione rozwiązania opisane w motywie 152 decyzji w sprawie SA.43697. Należy podkreślić, że rozwiązaniem bazowym i docelowym do wdrożenia była wprowadzona zmiana sposobu opodatkowania elektrowni wiatrowych. Drugie z rozwiązań - polegające na dostosowaniu poziomu cen referencyjnych dla farm wiatrowych było rozwiązaniem awaryjnym. Wynika to z treści motywu 152, który stanowi, że: „The Polish authorities committed that, if for any reason independent from the Polish government the provisions for the real property fax would not be introduced in the RES Act in time, the reference prices for the wind technologies in the auctions to be held in 2018 will be amended in order to take into account a higher tax burden". Za taką niespodziewaną i niezależną od polskiego rządu przyczynę można uznać, np. przedłużające się konsultacje publiczne - obowiązkowy etap rządowego procesu legislacyjnego. To w takim kształcie, jako propozycja rozwiązania głównego i awaryjnego, polskie stanowisko zostało zaakceptowane przez Komisję Europejską.

Należy również wyjaśnić, że przyjęcie drugiego z omówionych przez Komisję rozwiązań (polegającego na dostosowaniu poziomu cen referencyjnych dla farm wiatrowych) pozwoliłoby na ograniczenie negatywnych konsekwencji na gruncie prawa pomocy publicznej związanych ze zróżnicowanym podatkowym traktowaniem farm wiatrowych, jedynie w zakresie związanym ściśle z aukcyjnym mechanizmem wsparcia OZE. Należy bowiem zwrócić uwagę, że zagadnienie dotyczące zasad opodatkowania podatkiem od nieruchomości farm wiatrowych zostało zaadresowane w decyzji w sprawie SA.43697 jedynie w takim w zakresie, w jakim kwestia ta miała wpływ na dopuszczalność pomocy publicznej w ramach analizowanego przez Komisję Europejską aukcyjnego mechanizmu wsparcia OZE. Wyłącznie z tego powodu w motywie 152 decyzji w sprawie SA.43697 Komisja dopuściła dwa alternatywne rozwiązania w zakresie opodatkowania farm wiatrowych. Wprowadzenie rozwiązania alternatywnego nie pozwalałoby natomiast na 
eliminację ryzyka zainicjowania przez Komisję Europejską formalnej procedury dochodzeniowej (na podstawie art. 108 ust. 2 Traktatu o funkcjonowaniu UE) w odniesieniu do samych zasad opodatkowania podatkiem od nieruchomości operatorów instalacji wytwarzających energię elektryczną. Otwarcie formalnej procedury dochodzeniowej, która, z dużym prawdopodobieństwem, mogłaby zostać zakończona wydaniem decyzji nakazującej zwrot pomocy publicznej przez innych wytwórców niż operatorzy farm wiatrowych, przyniosłoby negatywne skutki dla wielu wytwórców energii z OZE. Biorąc pod uwagę, że w ówczesnym czasie Komisja Europejska już dwukrotnie rozpoczynała formalną procedurę dochodzeniową dotyczącą pomocy publicznej w sprawach instrumentów podatkowych w Polsce (decyzja KE z dnia 19 września 2016 r. w sprawie pomocy państwa SA.44351 (2016/C) (ex 2016/EO) - Polska - Podatek od sprzedaży detalicznej w Polsce oraz decyzja KE z dnia 15 stycznia 2018 r. w sprawie pomocy państwa SA.46981 (20 16/C) (ex 20 16/N) - Polska - Zryczałtowany podatek od wartości sprzedanej produkcji w przemyśle okrętowym), z czego jedna z tych procedur została zakończona wydaniem decyzji negatywnej (decyzja Komisji (UE) 2018/160 z dnia 30 czerwca 2017 r. w sprawie pomocy państwa SA.44351 (2016/C) (ex 2016/NN) wdrożonej przez Polskę w odniesieniu do podatku od sprzedaży detalicznej, Dz. Urz. UE L 29 z 1.2.2018, s. 38), Rada Ministrów uznała, że przywrócenie poprzednich zasad opodatkowania farm wiatrowych podatkiem od nieruchomości stanowi optymalne rozwiązanie, które pozwoli na uniknięcie wieloletnich postępowań przed sądami unijnymi oraz da Komisji podstawę do oddalenia ww. skargi" (pismo ME, s. 6-7).

Po uwzględnieniu tych wyjaśnień trudno uznać, że rację ma wnioskodawczyni nr 2, twierdząc, że celem samym w sobie omawianych zmian była nie ochrona jakichkolwiek wartości, ale zmniejszenie obciążeń publicznoprawnych pewnej grupy przedsiębiorców. Jakkolwiek bowiem nowelizacja miała na celu zmniejszenie konkretnego rodzaju obciążeń podatkowych, do których doszło w sposób nieprzewidziany i które nigdy nie były celem ustawodawcy, to efekt ten nie stanowił celu samego w sobie. Należy go postrzegać raczej jako cel pośredni, narzędzie ochrony ważniejszych wartości - swobody prowadzenia działalności gospodarczej, równości podmiotów wobec prawa (w tym przypadku przedsiębiorców prowadzących elektrownie wiatrowe, którzy zostali obciążeni podatkiem nieproporcjonalnie większym niż pozostali producenci energii ze źródeł odnawialnych) czy bezpieczeństwa prawnego jednostki.

Trzeba bowiem przypomnieć, że wartością uzasadniającą przyjęcie zmian w definicji elektrowni wiatrowej jako budowli ze skutkiem retroakcyjnym była przede wszystkim swoboda działalności gospodarczej właścicieli elektrowni wiatrowych, którzy w wyniku zmiany definicji budowli uiszczali 3-4 razy wyższy podatek od nieruchomości. Jak podkreślało w swoim stanowisku Polskie Stowarzyszenie Energetyki Wiatrowej [dalej: PSEW]: „jest [owo obciążenie - uwaga K.M.-D.] obciążeniem finansowym niejednokrotnie poddającym w wątpliwość 
ekonomiczną zasadność przedsięwzięcia i będzie skutkowało niemożnością obsługi zadłużenia bankowego inwestycji oraz wiodło wprost do masowych bankructw przedsiębiorstw sektora energetyki wiatrowej" (Stanowisko Polskiego Stowarzyszenia Energetyki Wiatrowej w sprawie niezbędnych zmian prawa określającego podstawę naliczania podatku od nieruchomości od elektrowni wiatrowych, dostęp online: https://www.senat.gov.pl/gfx/senat/userfiles/_public/ k9/komisje/2017/kpcpp/materialy/143/stanowisko_psew-podatek_od_nieruchomosci_uoi.pdf).

5. Wprowadzone ustawą zmieniającą unormowania skutkujące zmianą definicji budowli przywróciły zasady opodatkowania podatkiem od nieruchomości, które obowiązywały przed 1 stycznia 2017 r., rozstrzygając tym samym liczne wątpliwości podnoszone przez jednostki samorządu terytorialnego w postępowaniach przed sądami administracyjnymi. Trzeba bowiem odnotować, że w związku ze zmianami normatywnymi w prawie budowlanym w zakresie definiowania elektrowni wiatrowej jako budowli powstał spór, dotyczący wpływu zmian $\mathrm{w}$ prawie budowlanym na określenie przedmiotu opodatkowania $\mathrm{w}$ podatku od nieruchomości. W interpretacjach wydawanych na wniosek właścicieli elektrowni organy podatkowe zajmowały niejednolite stanowisko. Natomiast wojewódzkie sądy administracyjne jednolicie opowiedziały się za poglądem o zmianie definicji budowli również na potrzeby podatku od nieruchomości i tym samym za opodatkowaniem elektrowni wiatrowej jako budowli składającej się z części budowlanych i elementów technicznych. W tym stanie NSA postanowieniem z 15 maja 2018 r. przedstawił do rozpoznania składowi siedmiu sędziów następujące zagadnienie prawne budzące poważne wątpliwości: „Czy w stanie prawnym obowiązującym od 1 stycznia $2017 \mathrm{r}$. budowlą w rozumieniu art. 1a ust. 1 pkt 2 ustawy z dnia 12 stycznia 1991 r. o podatkach i opłatach lokalnych (Dz.U. z 2016 r., poz. 716 ze zm.) w zw. z art. 3 pkt 1 ustawy z dnia 7 lipca 1994 r. Prawo budowlane (Dz.U. z 2016 r., poz. 290 ze zm.) jest tylko część budowlana (wzniesiona z użyciem wyrobów budowlanych) elektrowni wiatrowej czy też budowlę tę stanowi fundament, wieża i elementy techniczne elektrowni wiatrowej, o których mowa w art. 2 pkt 1 i 2 ustawy z dnia 20 maja 2016 r. o inwestycjach w zakresie elektrowni wiatrowych (Dz.U. z 2016 r., poz. 961)?”.

Odpowiadając na tak sformułowany problem, NSA w powiększonym składzie wywiódł, iż „wypada tu zaznaczyć, że w wyniku zmian legislacyjnych dokonanych ustawą z dnia 7 czerwca 2018 r. o zmianie ustawy o odnawialnych źródłach energii oraz niektórych innych ustaw (Dz. U. z 2018 r. poz. 1276), m.in. $\mathrm{w}$ art. 3 pkt 3 u.p.b., katalog budowli zawarty w art. 3 pkt 3 u.p.b. został jednoznacznie uzupełniony o „części budowlane urządzeń technicznych (kotłów, pieców przemysłowych, elektrowni jądrowych, elektrowni wiatrowych i innych urządzeń)". Ustawodawca przywrócił zatem w tym zakresie brzmienie przepisu w stanie prawnym obowiązującym do 15 lipca 2016 r. Oznacza to, że w świetle obowiązujących obecnie unormowań nie budzi polemik identyfikacja przedmio- 
tu opodatkowania podatkiem od nieruchomości” (wyrok NSA w składzie 7 sędziów z 22 października 2018 r., sygn. akt II FSK 2983/17).

Takie odczytanie przez NSA konsekwencji przyjęcia zmian w definicji elektrowni wiatrowej jako budowli jest zbieżne z zamierzeniami projektodawców ustawy zmieniającej, którzy w uzasadnieniu do projektu ustawy podkreślili, iż „W zakresie zmian wprowadzanych $\mathrm{w}$ art. 2, wejście w życie zmiany dotyczącej art. 3 pkt 3 ustawy - Prawo budowlane, zawierającej definicję budowli oraz dotyczącej załącznika do tej ustawy, spowoduje wprowadzenie jednolitych i przejrzystych zasad opodatkowania podatkiem od nieruchomości" (druk sejmowy nr 2412/VIII kad.), czego wymaga z kolei standard płynący z art. 217 Konstytucji.

Jak wynika ze stanowiska PSEW, „[u]trzymanie poprzedniego stanu niepewności co do przedmiotu opodatkowania spowodowałoby wieloletnie spory inwestorów z gminami, co w konsekwencji oznaczałoby bankructwo większości farm wiatrowych w kraju. Potwierdzają to pierwsze instalacje, które niestety już musiały zgłosić upadłość nie wytrzymując takiego obciążenia” (dostęp online: https://podatki.gazetaprawna.pl/artykuly/1230231,gminy-nie-straca-na-zmianach-podatkow-od-wiatrakow.html).

Podsumowując powyższe ustalenia, należy uznać, że wbrew twierdzeniom zawartym we wnioskach, okoliczności uzasadniające odstąpienie od zasady lex retro non agit $\mathrm{w}$ analizowanym przypadku motywowane są wartościami aprobowanymi konstytucyjnie. Tym samym kontestowana regulacja spełniła przesłanki usprawiedliwiające, w świetle orzecznictwa Trybunału Konstytucyjnego, dopuszczalność retroaktywnego działania prawa (m.in. wyrok TK z 12 maja 2009 r., sygn. akt P 66/07).

Uzupełniająco należy także wskazać, że mechanizm retroakcji akceptowany jest przez ustawodawcę zwykłego, który przewidział możliwość jego zastosowania, „jeżeli zasady demokratycznego państwa prawnego nie stoją temu na przeszkodzie" (art. 5 ustawy z 20 lipca 2000 r. o ogłaszaniu aktów normatywnych, t.j. Dz. U. 2019, poz. 1461). Na gruncie analizowanej sprawy, antycypując ustalenia dotyczące oceny co do zgodności kwestionowanej regulacji z dalszymi zasadami wywodzonymi z art. 2 Konstytucji, trzeba stwierdzić, że art. 17 ust. 2 ustawy zmieniającej należy kwalifikować jako dopuszczalny wyjątek od reguły prospektywnego działania prawa.

6. Odnosząc się do zarzutu naruszenia zasady ochrony zaufania do państwa i stanowionego przez nie prawa, trzeba uznać za stosowne wskazanie, że prace nad projektem ustawy zmieniającej, który trafił pod obrady parlamentu z przedłożenia rządowego, poprzedzone były szeroko zakrojonymi konsultacjami społecznymi, których początek datowany jest na czerwiec 2017 r. Kontestowany przepis z przyczyn technicznych nie mógł istnieć w swojej ostatecznej wersji na etapie konsultacji publicznych, te bowiem były prowadzone w 2017 r., kiedy wciąż istniały realne szanse na wejście w życie ustawy do końca 2017 r. Skutek retroaktywny nie był zatem wówczas rozważany jako potrzebny. Natomiast 
nie można uznać, że wprowadzenie art. 17 pkt 2 ustawy zmieniającej było dla gmin zaskoczeniem. Przepis ten pojawił się na etapie rządowych prac legislacyjnych, określenie takiej daty wstecznej stosowania nowych definicji było środkiem do osiągnięcia zamierzonych celów w sytuacji, kiedy wejście w życie całego aktu opóźniało się z uwagi na skomplikowany proces legislacyjny, $\mathrm{w}$ tym proces uzgodnień. Jednostki samorządu terytorialnego, śledząc przebieg prac nad projektem ustawy zmieniającej (dostępnym do publicznej wiadomości), mogły uwzględnić w swoich założeniach planów budżetowych ewentualne zmiany, jakie zakładał ów projekt $\mathrm{w}$ zakresie zmiany przedmiotu opodatkowania podatkiem od nieruchomości.

W odpowiedzi na uwagi krytyczne podczas debaty parlamentarnej nad kwestionowanym przepisem sekretarz stanu w Ministerstwie Energii Grzegorz Tobiszowski, wskazywał, że: „w świetle tego, co mówią niektórzy przedstawiciele samorządów, że budowały budżet, mając inne założenia, chcę powiedzieć, iż informacja na temat planowanego przepisu znana była publicznie od czerwca 2017 r., czyli rok temu. Wraz z rozpoczęciem procedowania i międzyresortowych ustaleń upubliczniliśmy ustawę, założenia i ten przepis. Ponadto rozpowszechnialiśmy informacje przez pana dyrektora reprezentującego departament i ministerstwo. Mówiliśmy o tym podczas negocjacji i konsultacji społecznych, wskazując na intencję przepisu. Dzięki tym informacjom niektóre gminy zwróciły się do nas z prośbą o zinterpretowanie planowanego przepisu. Roztropni posiadali informację. Sądzę, że wszyscy ją mieli. Pozostała kwestia włodarzy miast, którzy w sporze $\mathrm{z}$ rządem chcą osiągnąć pewne rozstrzygnięcia. Myślę, że po dzisiejszej prezentacji na Radzie Ministrów warto, żeby parlamentarzyści przyjrzeli się, jak dzięki uszczelnieniu podatkowemu wzrosły przychody z podatków w samorządach. Samorządy często krzyczą, że mają dokonywać pewnych przedsięwzięć, jeśli chodzi o plany inwestycyjne, a nie mają na to środków uzupełniających. Tymczasem bardzo znacząco (nie o 1\% lub 5\%) wzrosły przychody samorządów dzięki uszczelnieniu systemu podatkowego. Dotyczy to kolejnych lat, począwszy od 2016 r. Można dochodzić swoich praw, ale myślę, że ci, którzy właściwie oceniają rzeczywistość i zachowują się racjonalnie mogli swoje budżety konstruować inaczej. Po drugie, mogli zastosować ulgi, które leżą w możliwości podejmowania przez nich decyzji, prowadząc politykę fiskalną w swoich gminach. Dziękuję parlamentarzystom za głosy, ale zapewniam, że ministerstwo nikogo nie chciało zaskakiwać lub być przeciwko samorządom, wręcz przeciwnie, mówiliśmy o planowanych przepisach od dawna, aby szczególnie wójtowie mogli racjonalnie budować swoje budżety" [Pełny zapis przebiegu posiedzenia Komisji do Spraw Energii i Skarbu Państwa (nr 103), 22 maja 2018 r., s. 23-24].

$\mathrm{W}$ podobnym tonie, uzasadniając przyjęcie retroaktywnego skutku zmiany $\mathrm{w}$ zakresie definicji elektrowni wiatrowej na potrzeby opodatkowania jej podatkiem od nieruchomości, sekretarz stanu w Ministerstwie Energii G. Tobiszowski wypowiedział się podczas 63. posiedzenia Sejmu Rzeczypospolitej Polskiej 
w dniu 5 czerwca 2018 r.: „jeśli chodzi o wycofanie się z podatku - to pytanie zadał pan poseł Mężydło - w kontekście innowacyjności i nowoczesnych technologii, to tak, rzeczywiście w ustawie, jak państwo wiecie, uwzględniamy kwestie modernizacji i kładziemy akcent na to, żeby pojawiły się najnowsze technologie, które stosujemy, jeśli chodzi o OZE i wiatraki, na polskim rynku. Natomiast jeśli chodzi o wycofanie się z podatku, to jednak uważamy, że jeżeli poprawiamy status podatkowy osób, które są objęte tym podatkiem, to nawet jeśli działamy pół roku do tyłu, to jesteśmy w zgodzie z konstytucją, bo tutaj poprawiamy tę sytuację. Wiemy, że niektóre gminy podnoszą tę kwestię, natomiast chcę powiedzieć, że prace konsultacyjne, jak państwo wiecie, [...] trwały ponad rok, i już wtedy mówiliśmy, że takie regulacje wejdą w życie. Stąd przedstawialiśmy tę informację również na spotkaniach z instytucjami, które reprezentują gminy wiejskie, i tam to podawaliśmy, dlatego też gminy, które planowały swój budżet, miały już informację, że taka regulacja powinna się pojawić w ustawie, która będzie uchwalana w połowie roku. W związku z tym uważamy, że nie powinniśmy, jeśli chodzi o rozstrzygnięcia, mieć problemu, ale jak mówię, nie chcę wypowiadać się za stosowne sądy" (Sprawozdanie stenograficzne z 63. posiedzenia Sejmu Rzeczypospolitej Polskiej w dniu 5 czerwca 2018 r. (pierwszy dzień obrad)), Warszawa 2018, s. 25-26).

W kontekście uzasadnienia wniosku nr 1 Sejm zauważa, że wnioskodawczyni nr 1 postrzega, iż zmiana przepisów ustawowych w zakresie definicji przedmiotu opodatkowania w trakcie roku spowodowała naruszenie zasad ochrony zaufania do państwa i stanowionego przez nie prawa oraz samodzielności finansowej gminy, rozumianej jako gwarancja odpowiedniego, niezmiennego poziomu dochodów jednostki samorządu terytorialnego.

Jak wskazuje Trybunał, „zasady ochrony zaufania obywatela do państwa i prawa oraz bezpieczeństwa prawnego wynikają z klauzuli demokratycznego państwa prawnego i mają charakter wiążący dla ustawodawcy. Odstąpienie od tych zasad mogłoby nastąpić w sytuacji szczególnej konieczności uzasadnionej interesem publicznym” (wyrok TK z 12 stycznia 2000 r., sygn. akt P 11/98). Jednocześnie „zasad tych nie można jednak rozumieć jako nakazu niezmienności prawa i zakazu ingerencji ustawodawcy w stosunki prawne rozciągnięte w czasie, zwłaszcza w tych dziedzinach życia społecznego, które podlegają szybkim zmianom faktycznym, jak to ma miejsce w polskiej gospodarce. Zasady te wyznaczają natomiast warunki, od których zależy ocena dopuszczalności zmian stanu prawnego" (wyrok TK z 7 maja 2001 r., sygn. akt K 19/00).

Trybunał wielokrotnie przypominał również, że zasada niezmienności prawa podatkowego w trakcie roku podatkowego również nie ma charakteru bezwzględnego. Zgodnie z poglądem Trybunału wyrażonym w wyroku z 25 kwietnia 2001 r., sygn. akt K 13/01, „Trybunał w swoim orzecznictwie nie wyrażał nigdy stanowiska o absolutnym charakterze zakazu zmian $\mathrm{w}$ prawie podatkowym w ciągu roku podatkowego, w szczególności tam gdzie chodzi o cofnięcie 
ulg lub przywilejów. Zmiany takie zawsze jednak powinny być usprawiedliwione balansowaniem wchodzących w grę wartości konstytucyjnych".

Uwzględniając te ustalenia trybunalskie, Sejm staje na stanowisku, że ustawodawcy przyjmującemu kwestionowane we wnioskach unormowanie przyświecała konieczność interwencji uzasadnionej tymi samymi wartościami konstytucyjnymi, które usprawiedliwiały odstąpienie od zakazu retroaktywności, a które zostały omówione w punkcie V.2.2-5 niniejszego stanowiska.

7. Warto także dodać, że przyjęcie kwestionowanego przepisu ustawy zmieniającej nie oznaczało automatycznie obowiązku zwrotu inwestorom nadpłaconego podatku od nieruchomości za okres od 1 stycznia 2018 r. do 30 czerwca 2018 r. Nadpłata powstała na skutek zapłacenia jednostce samorządu terytorialnego przez pierwsze miesiące roku 2018 rat uwzględniających opodatkowanie części technicznych elektrowni, mogła zostać przeksięgowana na poczet kolejnych rat podatku za rok 2018, a nawet przyszłych zobowiązań podatkowych inwestora z tytułu podatku od nieruchomości w kolejnych latach. W ten sposób jednostki samorządu terytorialnego mogły zachować uzyskane środki w swojej dyspozycji, planując na kolejny rok podatkowy (2019) niższe wydatki, bez konieczności poszukiwania środków na zwrot podatku inwestorom. Rozwiązanie takie zakładało oczywiście dialog i współpracę jednostek samorządu terytorialnego i podmiotów prowadzących elektrownie wiatrowe, jednak z doniesień PSEW wynika, że przedsiębiorcy taką gotowość wykazywali (dostęp online: https://podatki.gazetaprawna.pl/ artykuly/1230231,gminy-nie-straca-na-zmianach-podatkow-od-wiatrakow.html).

Jednocześnie trzeba wskazać na możliwość skorzystania przez jednostki samorządu terytorialnego, które w wyniku przyjętej w art. 17 pkt 2 ustawy zmieniającej regulacji utraciły część swoich dochodów planowanych na rok 2018, z uwagi na zmniejszenie wpływów z tytułu podatku od nieruchomości (od elektrowni wiatrowych), $\mathrm{z}$ instrumentu korekty do informacji finansowej w perspektywie danych o podstawowych dochodach podatkowych, mających wpływ na wysokość subwencji z budżetu państwa. Zgodnie z art. 32 ust. 2 ustawy o dochodach jednostek samorządu terytorialnego jednostki te mogą do 30 czerwca roku bazowego korygować dane o planowanych dochodach. Stosowna korekta, uwzględniająca zmniejszony dochód z tytułu podatku od nieruchomości, mogłaby mieć wpływ na uzyskanie większej kwoty subwencji z budżetu centralnego. Ograniczenie temporalne zgłoszenia korekty powiązane jest $\mathrm{z}$ harmonogramem prac nad budżetem centralnym, do którego wydatków zaliczane są subwencje ogólne i który planuje także wpływy z wpłat korekcyjno-wyrównawczych z przeznaczeniem na część równoważącą subwencji ogólnej.

8. Powyższe argumenty uzasadniają wniosek Sejmu o stwierdzenie, że art. 17 pkt 2 ustawy zmieniającej jest zgodny z zasadami: nieretroakcji prawa, ochrony zaufania do państwa i stanowionego przez nie prawa oraz niezmienności prawa podatkowego $\mathrm{w}$ trakcie roku podatkowego, wywodzonymi z art. 2 Konstytucji, w związku z art. 167 ust. 3 Konstytucji. 


\section{Bibliografia}

NIK, „Rozwój sektora odnawialnych źródeł energii” raport z 15 listopada 2018 r., https:// www.nik.gov.pl/pliklid, 18357, vp,20955.pdf.

Skoczylas A., Piątek W., Komentarz do art. 167 [w:] Konstytucja RP. Komentarz, t. II, Art. 87-243, red. M. Safjan, L. Bosek, Warszawa 2016.

Sprawozdanie stenograficzne $z$ 63. posiedzenia Sejmu Rzeczypospolitej Polskiej $w$ dniu 5 czerwca 2018 r. (pierwszy dzień obrad), Warszawa 2018.

Stanowisko Polskiego Stowarzyszenia Energetyki Wiatrowej w sprawie niezbędnych zmian prawa określającego podstawę naliczania podatku od nieruchomości od elektrowni wiatrowych, https://www.senat.gov.pl/gfx/senat/userfiles/_public/k9/komisje/2017/kpcpp/materialy/143/stanowisko_psew-podatek_od_nieruchomosci_uoi. pdf.

Tuleja P., Komentarz do art. 2 [w:] Konstytucja RP. Komentarz, t. I, Art. 1-86, red. M. Safjan, L. Bosek, Warszawa 2016.

Wojtyczek K., Ciężar dowodu i argumentacji w procedurze kontroli norm przez Trybunał Konstytucyjny, „Przegląd Sejmowy” 2004, nr 1.

Https://www.gramwzielone.pl/energia-wiatrowa/27369/bankructwa-wlascicieli-wiatrakow-sa-faktem.

Https://www.gov.pl/web/aktywa-panstwowe/krajowy-plan-na-rzecz-energii-i-klimatu-na-lata-2021-2030-przekazany-do-ke.

Https://podatki.gazetaprawna.pl/artykuly/1230231,gminy-nie-straca-na-zmianach-podatkow-od-wiatrakow.html. 